\title{
Multi-Modal Regulation of Circadian Physiology by Interactive Features of Biological Clocks
}

\author{
Yool Lee *(1) and Jonathan P. Wisor \\ Department of Translational Medicine and Physiology, Elson S. Floyd College of Medicine, \\ Washington State University, Spokane, WA 99202, USA; j_wisor@wsu.edu \\ * Correspondence: yool.lee@wsu.edu
}

check for updates

Citation: Lee, Y.; Wisor, J.P. Multi-Modal Regulation of Circadian Physiology by Interactive Features of Biological Clocks. Biology 2022, 11, 21. https://doi.org/10.3390/ biology11010021

Academic Editors: Jacek Z. Kubiak and Malgorzata Kloc

Received: 7 December 2021

Accepted: 23 December 2021

Published: 24 December 2021

Publisher's Note: MDPI stays neutral with regard to jurisdictional claims in published maps and institutional affiliations.

Copyright: (C) 2021 by the authors. Licensee MDPI, Basel, Switzerland. This article is an open access article distributed under the terms and conditions of the Creative Commons Attribution (CC BY) license (https:// creativecommons.org/licenses/by/ $4.0 /)$.
Simple Summary: Circadian rhythms, driven by molecular clockwork, exist in nearly all cells and tissues throughout the body, and these rhythmic oscillators constitute tightly coupled network systems that generate rhythmic physiology and behavior. Common circadian disrupting factors, such as night shift work and mistimed eating, can increase the risk of disease onset and symptoms. Disease can then, in turn, promote circadian disruption, leading to a vicious cycle of adverse circadian and overall health effects. This relationship suggests the importance of well-coordinated internal clock systems that maintain optimal synchrony with environmental and metabolic cues. In this review, we will recount the recent advances in circadian clock research and discuss how circadian clocks reciprocally interact with other signaling and metabolic factors to coordinate the daily rhythms of physiology.

\begin{abstract}
The circadian clock is a fundamental biological timing mechanism that generates nearly $24 \mathrm{~h}$ rhythms of physiology and behaviors, including sleep/wake cycles, hormone secretion, and metabolism. Evolutionarily, the endogenous clock is thought to confer living organisms, including humans, with survival benefits by adapting internal rhythms to the day and night cycles of the local environment. Mirroring the evolutionary fitness bestowed by the circadian clock, daily mismatches between the internal body clock and environmental cycles, such as irregular work (e.g., night shift work) and life schedules (e.g., jet lag, mistimed eating), have been recognized to increase the risk of cardiac, metabolic, and neurological diseases. Moreover, increasing numbers of studies with cellular and animal models have detected the presence of functional circadian oscillators at multiple levels, ranging from individual neurons and fibroblasts to brain and peripheral organs. These oscillators are tightly coupled to timely modulate cellular and bodily responses to physiological and metabolic cues. In this review, we will discuss the roles of central and peripheral clocks in physiology and diseases, highlighting the dynamic regulatory interactions between circadian timing systems and multiple metabolic factors.
\end{abstract}

Keywords: circadian clock; circadian disruption; SCN; brain clocks; peripheral clocks; redox metabolism

\section{Introduction}

Since the formation and settlement of our solar system roughly 4.5 billion years ago, the Earth has been rotating on its axis and revolving around the Sun, bringing about continuous light and dark cycles on this planet. In accordance with these cycles, nearly all living unicellular and multicellular organisms have evolved rhythmic life processes controlled by the circadian clock (from the Latin phrase circa diem meaning "about a day"), which have about $24 \mathrm{~h}$ periods and constantly predict and adapt to daily environmental changes [1] This internal timing system is believed to help organisms survive by increasing their ability to timely anticipate the cyclic changes of light and food availability as well as predation risk. At the unicellular level, the timely compartmentalization of the organism's biochemical, metabolic, and redox processes, coordinated by the intrinsic clockwork, ensures the temporal fitness of cell physiology and functions across species [2]. In lower eukaryotic 
species, biological timers may help single-celled organisms escape the DNA-damaging effects of ionizing radiation from sunlight as well as oxidative stress during cell division [3] In higher, complex organisms, including humans, common cellular oscillators constitute the brain and peripheral tissue clocks that interconnect to form a circadian network at the whole-body level. Interestingly, human or cross-species studies reveal differences in behavioral chronotype not only between species but also within and between different individuals of each species, suggesting the extent of intra- and inter-subject variability of circadian timing systems [4-8]. With periodic anticipation and synchronization to daynight cycles, these internal timing systems, in concert, coordinate rhythmic physiology and behaviors such as the sleep-wake cycle, body temperature, blood pressure, hormone production, neural and immune system processes, and cell proliferation $[9,10]$.

In contrast to the adaptive benefits of circadian rhythms, modern lifestyles result in misalignment of the working, eating, and sleeping cycles, relative to natural $24 \mathrm{~h} \mathrm{light/dark}$ cycles, that historically defined human existence. Such misalignment has been found to increase our susceptibility to the onset and development of cardiometabolic, digestive, immune, and neuropsychiatric disorders, as well as cancers [11-14]. Several studies in animal models containing genetic mutations of clock genes or those exposed to forced circadian desynchrony regimens have also reinforced the causal relationship between circadian disturbances and disease pathologies [15-20]. Furthermore, increasing numbers of studies in cellular and animal models have reported that cellular and bodily rhythms are highly influenced by physiological and metabolic stimuli, such as diet, exercise, metabolites, ions, and gaseous molecules [21-23]. In this review, we will describe recent advances in chronobiology as well as the roles of central and peripheral clocks in physiology and diseases, with a particular focus on the dynamic interactions between biological timing systems and metabolic factors.

\section{Multi-Modal Mechanisms of Circadian Physiology}

The basic circadian rhythm mechanism, conserved across living species on earth, is typically characterized by a cell-autonomous autoregulatory feedback loop [3,24]. In eukaryotes, a subset of dedicated positive and negative clock regulators forms the interlocked transcriptional translational feedback loop (TTFL), which constitutes a cell-intrinsic oscillator that drives the rhythmic expression of output genes involved in metabolic, biosynthetic, and signal transduction pathways [9]. In mammals, the BMAL1 and CLOCK transcriptional activator complex cyclically drives the transcription of its own repressors, period (PER) and cryptochrome (CRY). The core oscillator is complemented by a second loop in which periodic expression of $B M A L 1$ is maintained by the REV-ERB $\alpha / \beta$ repressor and $R O R \alpha / \beta$ activator proteins [25] (Figure 1).

Besides the core regulatory loops, multiple levels of epigenetic, posttranscriptional, and posttranslational regulation involving various kinases and phosphatases, ubiquitinproteasome pathway components, nuclear-cytoplasmic transporters, non-coding RNAs, and chromatin remodelers contribute to the molecular clockwork, thus coordinating temporal programs via multiple clock-output genes involved in cellular physiology and metabolism [26-33]. Notably, recent large-scale genomic studies reveal that $\sim 50 \%$ of mammalian genes exhibit circadian regulation in at least one tissue, although the identity of genes expressed rhythmically varies from tissue to tissue [34-36]. In addition, multi-scale omics studies demonstrated circadian regulation of the epigenome, the metabolome, the proteome/phosphoproteome, and the microbiome [34,35,37-45]. These studies reveal that proteins or metabolites display different patterns of oscillations relative to transcript rhythms in a given tissue (e.g., hippocampus, liver), and oscillations at all levels can be reprogramed by circadian disturbances, such as sleep deprivation, jet lag, high-fat diet, and aging. 


\section{Transcriptional Rhythms}

(TR)

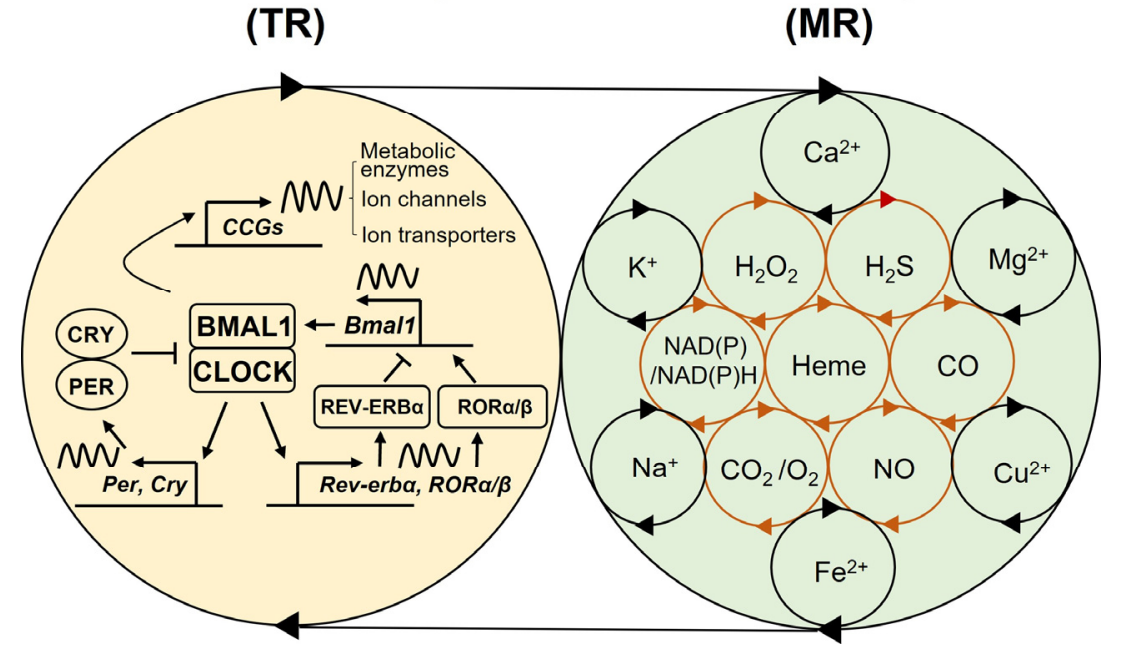

Figure 1. Coupled-cellular oscillators. Bidirectional regulation between transcriptional and metabolic rhythms. The auto-regulatory feedback cycles between the CLOCK/BMAL1 transcriptional activator complex and its transcriptional repressors (PER/CRY, REV-ERB $\alpha$ ) and activators $(\operatorname{ROR} \alpha / \beta)$, constituting the molecular clock oscillator. This oscillator drives the expression of multiple clock-controlled genes (CCGs), such as metabolic enzymes, ion channels, and transporters. The transcriptional rhythms (TR) mediate metabolic rhythms (MR) involving the cyclic synthesis, degradation, and transport (e.g., influx/efflux) of redox factors, gases, and ions, which, in turn, provide feedback that regulates the TR, constituting coupled-cellular oscillators.

In mammalian species, the circadian clock machinery is shared across the brain and peripheral organ systems, constituting a body-wide circadian network (Figure 2).

The intracellular oscillators, in approximately 20,000 neurons, comprise the hypothalamic suprachiasmatic nucleus (SCN), a central clock in the rodent brain. The SCN in humans has been found to contain a total number of neurons close to 100,000, though these numbers decline with age [46-48]. The SCN consists of different subtypes of neurons that express the neurotransmitter c-aminobutyric acid (GABA), an inhibitory neurotransmitter in the brain, alongside a range of neuropeptides such as vasoactive intestinal peptide (VIP), arginine vasopressin (AVP), and their cognate receptors (VPAC2 and AVPR1A/B) [49-52]. These GABAergic/peptidergic SCN neurons interact among themselves or with the other neurons in extra-SCN brain regions, constituting the main output pathway of the clock. Notably, a recent study has demonstrated that the VIP-VPAC2 neuropeptidergic axis plays a central role in mediating the endogenous pacemaking function of the SCN circadian circuit [53]. In line with this, the suprachiasmatic VIP neurons (SCNVIP) have been shown to be required for normal circadian behaviors via functional connectivity between SCN ${ }^{\mathrm{VIP}}$ neurons and dorsomedial hypothalamic neurons [54]. Interestingly, recent single-cell RNA sequencing (scRNASeq) studies with mouse SCN slice revealed novel neuronal phenotypes and interaction networks involved in the central clock, including the identification of five SCN neuronal subtypes, with cluster-specific marker genes of VIP, AVP, gastrin-releasing peptide (GRP), cholecystokinin (CCK), and the cell adhesion regulator C1ql3 [55,56]. Additional scRNASeq study has also identified a subgroup of cells expressing Prokineticin2 (Prok2) and its cognate receptor (ProkR2) found to be topologically and functionally distinct pacemaking element of the central clock [57]. Thus, these studies highlight diverse cellular sub-populations within the neuropeptidergic topology of the SCN, which may differently contribute to the central pacemaker function. Notably, recent studies have shown that astrocytes harbor distinct rhythmic properties, such as anti-phasic $\mathrm{Ca}^{2+}$ rhythms, that direct the circadian rhythmicity of SCN neurons and behavior [58-60]. This work suggests the importance of bipartite intercellular communication between astrocytes and neurons in modulating SCN pacemaker functions, beyond neuronal regulation of the central clock. 


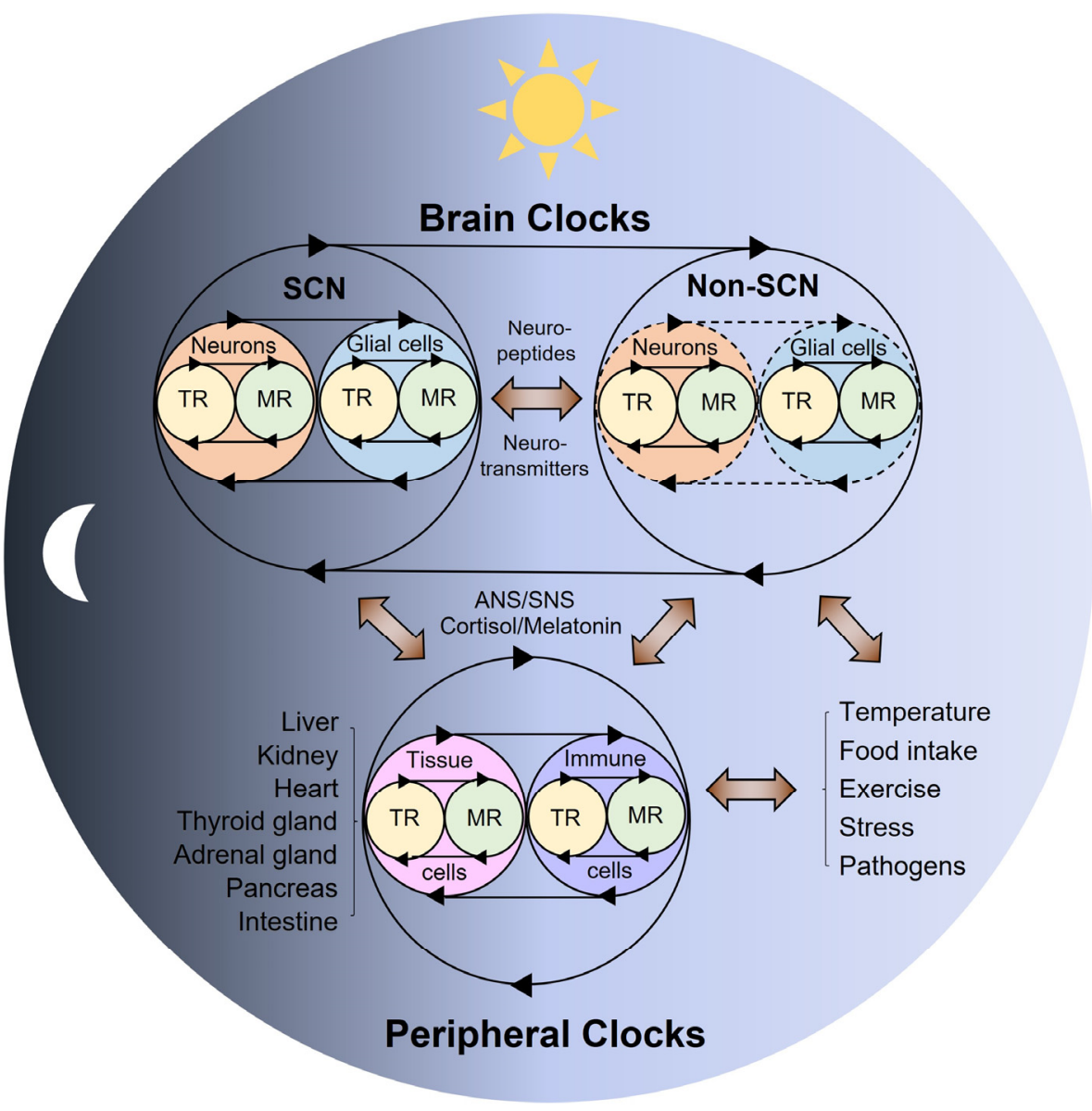

Figure 2. Coupled-tissue oscillators. Reciprocal crosstalk between the brain and peripheral clocks. The coupled TR and MR oscillators are thought to be commonly present across all body cells. Neurons and glial cells (e.g., astrocytes, microglia) interact to form the SCN central clock and non-SCN clocks in the brain. These autonomous brain clocks communicate with each other via neurotransmitters or neuropeptides, and with multiple peripheral tissue clocks via systemic innervations (ANS/SNS) or hormonal signals (e.g., cortisol, melatonin) in response to light-dark cycles. On the other hand, peripheral organs possess tissue autonomous clocks that can respond to non-photic physiological and environmental cues (e.g., temperature, food intake, exercise, stress) and provide feedback that influences the brain clocks via immune, metabolic, and endocrine signals. TR-transcriptional rhythms; MR-metabolic rhythms; ANS—autonomic nervous system; SNS—sympathetic nervous system.

Along with endogenous circadian pacemaking activity, the SCN central clock also mediates the periodic synchronization of internal body rhythms with external day and night cycles by communicating retinal light information received from the retinohypothalamic tract (RHT) to peripheral clock systems [26]. In a hierarchical organization model, the SCN master clock coordinates the circadian phases of individual subordinate clocks in other brain regions via rhythmic release of neurotransmitters and neuropeptides as well as in peripheral tissues via systemic hormonal secretion and neural innervations, thus generating rhythmic output physiology and behaviors that are in keeping with the daily changes in environment and needs [61-64]. For example, the SCN coordinates the rhythmic anti-phasic secretion of the night sleep hormone melatonin in the pineal gland and the morning stress hormone glucocorticoid in the adrenal glands via the sympathetic nervous system, ensuring daily rhythms in sleep/wake, as well as neural, metabolic, and immune functions [65-67]. In addition, the brain master clock controls peripheral clock functions in the heart, kidney, pancreas, lung, intestine, and thyroid glands by circadian regulation of the autonomic nervous system [68-73]. 
Besides SCN-driven clock entrainment, a growing number of studies have reported that non-SCN brain regions and peripheral tissues possess their own autonomous, entrainable oscillators that influence not only circadian functions in the SCN and neighboring local clocks, but also whole body rhythms via neural, hormonal, and metabolic feedback mechanisms [13,74-80]. The SCN receives a myriad of nonphotic input, arousal, feeding behavior, locomotor activity, immune function, blood pressure, and melatonin, which are all able to adjust and synchronize the SCN [81-84]. The SCN can receive this feedback through its large array of reciprocal neuronal connections with different hypothalamic regions, such as the arcuate nucleus (ARC), intergeniculate leaflet (IGL), nucleus tractus solitarius (NTS), dorsal raphe, and dorsomedial hypothalamus, allowing these nuclei to convey nonphotic feedback to the SCN and thus adjusting circadian rhythmicity [85-89].

Beyond photic entrainment, multiple physiological and environmental cues (e.g., food intake, gut microbial products, redox cofactors, metal ions, metabolic gases) control nonSCN and peripheral clock functions, which, in turn, impact the entire host clock system via neural and immune-metabolic circuits [12,22,72,90-95]. These findings suggest that systemic circadian rhythms are achieved through multi-modal regulation of tightly coupled body clocks according to daily changes that occur in the internal and external environments.

\section{The Role of Brain Clocks in Circadian Rhythms and Disorders}

The growing knowledge of cellular and tissue clock coupling mechanisms has increased our understanding of how rhythm disturbances of the SCN or locally distributed clocks within other tissues, caused by multiple physiological and environmental factors, impact circadian physiology and diseases at the whole-body level. Indeed, numerous animal studies have demonstrated pathological impacts of experimental circadian disruptions, such as surgical ablation of the SCN specific clock, whole-body knockout of core clock genes (i.e., Bmal1, Per1/2, Cry1/2, Rev-erb $\alpha / \beta$ ), and experimental jet lag (chronic phase shift by altered light schedules). These studies provide ample evidence for the increased risk of sleep, mood, cardiometabolic, immune, endocrine, digestive, reproductive, premature aging, neurodegenerative, and neoplastic disorders [13,69,71,96-102]. Accordingly, several human health and translational studies have reported similar adverse health consequences as a result of circadian clock gene polymorphisms, sleep deprivation, night shift work, and artificial light at night (LAN) exposure [103-106].

The recent development of a tissue-specific genetic disruption tool has provided further insights into the specific roles of the SCN and its surrounding brain regions in circadian rhythm regulation. Studies of mice with genetic ablation of Bmal1 in SCN neurons showed that peripheral clocks, as well as locomotor activity, were lost or compromised in constant darkness but remained rhythmic and synchronized to light-dark (LD) conditions [107,108]. This suggests that previously observed loss of circadian rhythms, even under LD cycles, in animals with surgical ablation of the SCN resulted from the elimination of SCN afferents [109-111]. In a similar study, forebrain/SCN-specific deletion of Bmal1 in mice resulted in the immediate loss of circadian behavior as well as desynchronized and dampened circadian rhythms in peripheral tissues under conditions of constant darkness [112]. However, the loss of behavior and peripheral synchrony was rescued by LD cycles and was partially rescued by restricted feeding [112]. Moreover, targeted deletion of Bmal1 in neurons and glia was found to exacerbate neurodegenerative pathologies and behaviors, despite the retention of intact circadian behavioral and sleep-wake rhythms under LD conditions [101]. In line with these findings, a recent study showed that the nuclear receptors Rev-erb $\alpha / \beta$ in the GABAergic ( $\gamma$-aminobutyric acid-producing) in neurons of the SCN (SCNGABA neurons) control the diurnal rhythm of insulin-mediated suppression of hepatic glucose production in mice, without affecting diurnal eating or locomotor behaviors during regular light-dark cycles [113]. These results suggest that the SCN central clock plays an important role in maintaining the internal synchrony of robust circadian programs in some peripheral clocks, while other peripheral clocks can be differentially modulated by light and feeding, regardless of the presence of a functional SCN central oscillator in the brain. 
Beyond the SCN's clock-modulatory functions, accumulating evidence has revealed a critical role for SCN-independent clock entrainment in circadian rhythms and disorders. Recent studies have shown that several brain regions outside the SCN (e.g., extraSCN hypothalamic nuclei, hippocampus, lateral habenula, choroid plexus) express SCNindependent or semi-autonomous intrinsic circadian rhythms that are sensitive to fluctuations in nutrients, behavioral arousal, and hormonal signals, particularly driven by daily food intake $[75,79,80]$. Through ablation or genetic perturbation, these studies revealed the important roles of non-SCN clock functions in modulating downstream body activities including metabolic rate, thermogenesis, food consumption, thirst, mood, and sleep $[75,79,80]$.

Notably, SCN-independent clocks can modulate the activity of the SCN oscillator itself. With the combined approaches of pharmacological inhibition and electrophysiological stimulation of the substantia innominata (SI) in the basal forebrain, a recent study has argued that the cholinergic basal forebrain is both a necessary and sufficient arousal input to the circadian pacemaker, mediating arousal-induced clock resetting [114]. These results may also explain why, in the absence of a functional SCN clock in the brain, behavioral rhythms, and peripheral clocks are still entrained when mice are kept under LD cycle conditions $[112,115]$. The SCN circuitry is thus capable of conveying rhythmicity secondarily to other oscillators. Consistent with these findings, another recent study using an in vitro tissue co-culture model revealed that the autonomous clock in the choroid plexus $(\mathrm{CP})$, the brain region responsible for cerebrospinal fluid (CSF) secretion, exceeds even the $\mathrm{SCN}$ clock in terms of robustness, perhaps determining the circadian period of behavioral locomotor activities by speeding up the SCN clock via the circulation of CSF [75]. In a parallel study, this $\mathrm{CP}$ oscillator was shown to be modulated by estrogens via a hormone receptor-dependent mechanism [116]. Together, these results indicate the physiological importance of non-SCN brain oscillator functions in mediating systemic regulation and environmental entrainment of biological clock function.

\section{The Role of Peripheral Clocks in Circadian Rhythms and Disorders}

In addition to the brain network of cellular oscillators, growing evidence suggests that self-driving clocks in peripheral tissues are critical for the systemic homeostasis of circadian physiology. An approach that has been applied extensively in this context is tissue-specific disruption of a core clock component, for instance, the bmal1 locus, paired with assessment of physiological and endocrinological functions of that tissue. Table 1 lists some examples of studies in which this approach has yielded novel insights into the function of peripheral clocks in physiology and endocrinology.

Table 1. A sampling of studies on the effects of tissue-specific Bmal1 ablation.

\begin{tabular}{|c|c|c|c|c|c|}
\hline $\begin{array}{l}\text { Cell type of } \\
\text { Selective } \\
\text { Bmal1 } \\
\text { Ablation }\end{array}$ & $\begin{array}{c}\text { Promoter } \\
\text { Controlling } \\
\text { Cell-Specific } \\
\text { Manipulation }\end{array}$ & $\begin{array}{l}\text { Rhythm(s) } \\
\text { Eliminated }\end{array}$ & $\begin{array}{l}\text { Effect on } \\
\text { Circadian } \\
\text { Behavior }\end{array}$ & $\begin{array}{c}\text { Clinical } \\
\text { Manifestation }\end{array}$ & $\begin{array}{l}\text { Citation } \\
\text { Number }\end{array}$ \\
\hline Adipocyte & $\begin{array}{l}\text { Adipocyte protein } 2 \\
(\mathrm{aP} 2) \text { gene promoter }\end{array}$ & Adiponectin & $\begin{array}{l}\text { Shift in the } \\
\text { diurnal rhythm } \\
\text { of food intake } \\
\text { and energy } \\
\text { expenditure }\end{array}$ & Obesity & [117] \\
\hline Adrenal & $\begin{array}{c}\text { Melanocortin 2 } \\
\text { Receptor (MC2R) } \\
\text { gene promoter, } \\
\text { Aldosterone synthase } \\
\text { (AS) gene promoter } \\
\text { data }\end{array}$ & $\begin{array}{c}\text { Circulating } \\
\text { corticosterone, } \\
\text { ACTH } \\
\text { sensitivity }\end{array}$ & $\begin{array}{l}\text { Attenuated } \\
\text { behavioral } \\
\text { rhythmicity }\end{array}$ & Hyperadrenocorticism & {$[76,118,119]$} \\
\hline
\end{tabular}


Table 1. Cont.

\begin{tabular}{|c|c|c|c|c|c|}
\hline $\begin{array}{l}\text { Cell type of } \\
\text { Selective } \\
\text { Bmal1 } \\
\text { Ablation }\end{array}$ & $\begin{array}{c}\text { Promoter } \\
\text { Controlling } \\
\text { Cell-Specific } \\
\text { Manipulation }\end{array}$ & $\begin{array}{l}\text { Rhythm(s) } \\
\text { Eliminated }\end{array}$ & $\begin{array}{l}\text { Effect on } \\
\text { Circadian } \\
\text { Behavior }\end{array}$ & $\begin{array}{c}\text { Clinical } \\
\text { Manifestation }\end{array}$ & $\begin{array}{l}\text { Citation } \\
\text { Number }\end{array}$ \\
\hline Hepatocyte & $\begin{array}{l}\text { Abumin }(\mathrm{ABL}) \text { gene } \\
\text { promoter }\end{array}$ & $\begin{array}{l}\text { Glucoregulatory } \\
\text { genes }\end{array}$ & None & $\begin{array}{l}\text { Increase glucose } \\
\text { clearance and } \\
\text { hypoglycemia } \\
\text { restricted to the } \\
\text { fasting phase }\end{array}$ & [120] \\
\hline $\begin{array}{c}\text { Pancreatic } \beta \\
\text { cell }\end{array}$ & $\begin{array}{c}\text { Pancreatic } \\
\text { Additionally, } \\
\text { Duodenal Homeobox } \\
1 \text { (PDX1) gene } \\
\text { promoter }\end{array}$ & $\begin{array}{l}\text { Insulin } \\
\text { secretion }\end{array}$ & None & Insulin resistance & [121] \\
\hline $\begin{array}{l}\text { Skeletal } \\
\text { muscle }\end{array}$ & $\begin{array}{l}\text { Human } \alpha \text {-skeletal } \\
\text { actin (HSA) gene } \\
\text { promoter }\end{array}$ & $\begin{array}{l}\text { Muscle } \\
\text { growth and } \\
\text { metabolism }\end{array}$ & $\begin{array}{c}\text { Sleep } \\
\text { disturbance }\end{array}$ & $\begin{array}{c}\text { Metabolic } \\
\text { inefficiency and } \\
\text { impaired muscle } \\
\text { triglyceride } \\
\text { biosynthesis }\end{array}$ & {$[122,123]$} \\
\hline Renal & $\begin{array}{l}\text { Kidney-specific } \\
\text { cadherin (KSP-Cad) } \\
\text { gene promoter }\end{array}$ & None & None & $\begin{array}{l}\text { Altered the plasma } \\
\text { metabolome, lowered } \\
\text { blood pressure in } \\
\text { male mice }\end{array}$ & {$[124,125]$} \\
\hline Intestine & $\begin{array}{l}\text { Villin (VIL1) gene } \\
\text { promoter }\end{array}$ & None & None & $\begin{array}{l}\text { Prevents obesity } \\
\text { induced by high-fat } \\
\text { feeding }\end{array}$ & [126] \\
\hline Cardiomyocyte & $\begin{array}{l}\text { Myosin heavy chain } \\
\alpha(\mathrm{MHC} \alpha) \text { gene } \\
\text { promoter }\end{array}$ & $\begin{array}{l}\text { Circadian gene } \\
\text { expression in } \\
\text { heart }\end{array}$ & None & $\begin{array}{l}\text { Diastolic dysfunction, } \\
\text { Impaired resolution } \\
\text { of inflammation, } \\
\text { Reduced life span }\end{array}$ & {$[127,128]$} \\
\hline
\end{tabular}

For example, in a prevailing model, the robust daily rhythm of glucocorticoid (GC; corticosterone (CS) in rodents and cortisol in primates) has generally been attributed to SCN-mediated modulation of the hypothalamic-pituitary-adrenal (HPA) stress response axis and sympathetic innervation of the GC secretory adrenal gland for the light entrainment of other peripheral clock systems $[65,66,129]$. On the other hand, Kim and colleagues have shown that the adrenal gland has its own autonomous clock that functions independently of the SCN, and that adrenal-specific disruption of Bmal1 dampens the circadian CS rhythm, impairing behavioral rhythmicity and gene expression cycling in several peripheral organs $[76,118]$. These findings correspond with another study showing that the adrenal-intrinsic oscillator controls a gating mechanism involved in circadian sensitivity to adrenocorticotropin (ACTH) produced by the pituitary gland $[119,130]$.

In another peripheral clock study, liver-specific Bmal1 deletion was shown to increase glucose clearance and hypoglycemia restricted to the fasting phase as a result of arrhythmic gene expression of glucose-related genes [120]. The systemic impact of the liver clock was further demonstrated in additional studies showing that dual Rev-erb $\alpha / \beta$ knockout specifically in the liver leads to increased circulating glucose and triglyceride levels, a reduction in free fatty acids (FFAs), as well as altered transcriptional, metabolic, and behavioral rhythms, compared with controls [131-133]. Notably, a more recent study revealed that circadian oscillations persist in the livers of mice devoid of an SCN or oscillators in cells other than hepatocytes, corroborating the independent nature of the liver clock [78].

Similar to liver cells, adipocytes harbor their own circadian clock. Disruption of this clock via adipocyte-specific deletion of Bmal1 results in obesity in mice, with a shift in the diurnal rhythm of food intake and energy expenditure, suggesting a central role for adipose tissue as an integrator of organismal energy balance [117]. In support of this idea, a recent study using an adiponectin (ADIPOQ)-deficient mouse model showed that this adipokine, which is produced primarily in adipose tissue to modulate glucose levels as well as fatty acid breakdown, regulates diurnal feeding rhythms through clocks in energy regulatory centers (e.g., arcuate nucleus (ARC)) of the mediobasal hypothalamus (MBH) [134]. The physiological implications of these mechanistic studies in animals are 
further underscored by previous human studies showing that in obese patients, ADIPOQ blood levels decline and the diurnal rhythms of ADIPOQ release are dampened $[135,136]$. On the other hand, another endocrine study showed that ablation of the pancreatic $\beta$ cell-autonomous clock in adult mice caused severe glucose intolerance along with altered insulin secretion [121]. Interestingly, the $\mathrm{O}^{\prime} \mathrm{Neill}$ group recently provided evidence of the role of insulin as a systemic timing cue to entrain circadian rhythms throughout the body by selective induction of the period clock proteins, with further demonstration of the circadian disruption recapitulated by mistimed insulin in cell and animal models [137].

Importantly, growing evidence suggests an independent physiological role for the skeletal muscle clock. Recently, Ehlen et al. reported that muscle-specific Bmal1 disruption and restoration in Bmal1-KO mice led to sleep disturbances and recovery, respectively; however, brain-specific restoration of BMAL1 expression did not rescue BMAL1-dependent sleep phenotypes, indicating that the skeletal muscle clock is both necessary and sufficient for normal sleep regulation [122]. In line with these findings, a subsequent study indicated that muscle-specific loss of BMAL1 is associated with metabolic inefficiency, impaired muscle triglyceride biosynthesis, and the accumulation of bioactive lipids and amino acids [123]. More recently, skeletal muscle was also shown to exhibit diurnal variations in muscle growth and metabolism, independent of locomotor activity [138]. Thus, it can be speculated that rhythmic metabolic signals from the skeletal muscle clock impact systemic energy homeostasis, thus regulating brain activity and sleep function.

Notably, emerging transcriptomic and metabolomic studies have reported that lung adenocarcinoma as well as pulmonary inflammation (e.g., asthma) can reprogram the circadian homeostasis of local and systemic physiology, leading to metabolic and sleep disturbances $[139,140]$. In line with the idea that local organ disease impacts circadian rhythms, a recent study using a chronic kidney disease (CKD) mouse model reported that kidney-specific clock disruption by CKD leads to unstable circadian behavioral rhythms, which may explain the sleep disturbances that are known to be associated with kidney failure [77]. It is assumed that the rhythmic readjustment of fluid homeostasis by the kidney affects the SCN clock, thereby altering circadian rhythms at the behavioral level [77]. Overall, the current evidence suggests that brain clocks as well as multiple regulatory feedback networks in the periphery contribute to circadian physiology and pathophysiology (Figure 2).

\section{The Role of Feeding in Circadian Rhythms and Disorders}

Besides the systemic impact of local clock dysfunction, growing evidence has emphasized the chrono-physiological importance of non-photic regulation of the body clock network. Several early studies showed that timed food administration affects peripheral clocks without altering the SCN $[141,142]$. However, recent comprehensive metabolomics studies demonstrated that nutritional challenges, such as a high-fat diet, metabolically reprogram the circadian rhythmicity of distinct brain areas, including the SCN, and peripheral clocks, thus altering the system-wide synchrony of the internal body clocks $[38,143,144]$. In addition to an unbalanced diet, short-term feeding at the wrong time is reported to be sufficient to desynchronize peripheral clocks and induce obesity along with hyperphagia, physical inactivity, and metabolic disorders in mice [145]. These observations from animal models are resonant with several human studies, reporting that food intake during the circadian evening and/or night is associated with increased body fat and obesity and reduced effectiveness of weight loss therapy in both adults and children [146-149]. Besides the metabolic impact, mistimed feeding was also shown to result in dramatic deficits in hippocampus-dependent learning and memory by reducing cyclic AMP response element binding protein (CREB)-mediated long-term potentiation in the hippocampus [150]. Moreover, a recent population-based case-control study reported that mistimed eating patterns increase the risk of breast and prostate cancer [151].

Notably, an increasing number of studies has revealed that the intestinal microbiota in both mice and humans exhibit diurnal oscillations in composition and activity, and that 
these rhythms are impaired by the ablation of host molecular clock components or the induction of jet lag, leading to gut dysbiosis and altered feeding rhythms [37,152-154]. The potential systemic impact of a dysregulated microbiome was further shown in a subsequent study indicating that the diurnal rhythmicity of the microbiota drives the global programming of host circadian transcriptional, epigenetic, and metabolite oscillations [90]. Interestingly, Chambon and colleagues from the analysis of large intestine showed that depletion of microbiota profoundly disrupts circadian clock in intestinal epithelial cells (IECs), leading to altering corticosteroids levels and consequent metabolic disorders [155]. This suggests a reciprocal influence between the gut epithelium of the host and the microbiota for each other's physiology that contributes to additional system-wide cyclic homeostasis. In line with these studies, Kuang et al. recently reported that cyclically induced expression of histone deacetylase 3 (HDAC3) in gut epithelial cells mediates the diurnal programming of the host's metabolism by the intestinal microbiota, the lack of which leads to diet-induced obesity [156]. Given the systemic modulation of both brain and peripheral clock functions by gut microbiome metabolites [157], it is plausible that the above pathological impact of mistimed feeding is associated, in part, with dysregulated gut-microbiome products. Together, these findings underscore the physiological and pathological significance of peripheral entrainment of host circadian systems in response to multiple internal and external cues.

\section{The Role of Metabolic Cues in Circadian Rhythms and Disorders}

Emerging studies suggest that multiple metabolic or nutritional components, such as redox cofactors, gases, and ions, are not only circadian-regulated components, but can also act as timing cues to regulate circadian physiology via reciprocal feedback mechanisms (Figure 1). Descriptions of some of these factors and their roles in circadian rhythms and disorders are detailed below.

\section{1. $N A D(P) / N A D(P) H$}

Nicotinamide adenine dinucleotide (NAD) (including NAD+ and NADH) and nicotinamide adenine dinucleotide phosphate (NADP) (including NADP+ and NADPH), via their electron transfer functions, are fundamental mediators of various biological processes, including energy metabolism, mitochondrial functions, anti-oxidation/generation of oxidative stress, gene expression, immunological functions, and aging [158]. Several lines of evidence suggest that $\mathrm{NAD}(\mathrm{P}) / \mathrm{NAD}(\mathrm{P}) \mathrm{H}$ are circadian-controlled or are circadian controlling factors. Previous studies have shown that intracellular NAD+ levels cycle with a $24 \mathrm{~h}$ rhythm driven by CLOCK:BMAL1-dependent circadian expression of nicotinamide phosphoribosyltransferase (NAMPT), a rate-limiting enzyme in the NAD+ salvage pathway $[159,160]$. In turn, the $\mathrm{NAD}(\mathrm{P}) / \mathrm{NAD}(\mathrm{P}) \mathrm{H}$ ratio impacts circadian rhythms at a molecular level both directly and indirectly. In an early in vitro study, Rutter et al. showed that the reduced forms of the redox cofactors NADH and NADPH strongly enhance DNA binding of CLOCK/Neuronal PAS Domain Protein 2 (NPAS2):BMAL1 heterodimers, whereas the oxidized forms of the cofactors (NAD+ and NADP+) inhibit binding [161]. In later studies, increasing NADH levels by inhibiting NAMPT was found to promote oscillation of the clock gene Per 2 by releasing CLOCK:BMAL1 from suppression by SIRT1, an NAD+-dependent protein deacetylase that was previously shown to counteract CLOCK acetylation and suppress CLOCK-BMAL1-mediated transactivation $[160,162]$. On the other hand, a recent study showed that NADPH depletion by pharmacological inhibition of the pentose phosphate pathway (PPP), an NADPH-generating pathway that is tightly connected to glycolysis, leads to the activation of CLOCK/BMAL1 by the histone acetyltransferase p300 [94]. These data suggest that the $\mathrm{NAD}(\mathrm{P}) / \mathrm{NAD}(\mathrm{P}) \mathrm{H}$ redox ratio can regulate CLOCK:BMAL1-dependent circadian function by affecting dimerization or epigenetic cofactor recruitment. Notably, a more recent study showed that NAD+ activation of SIRT1 rejuvenates circadian rhythms in old mice through inhibition of the clock repressor PER2 by protein deacetylation, which controls its phosphorylation-mediated nuclear entry 
and stability [163]. This finding is reminiscent of a previous result showing that SIRT1 binds to CLOCK-BMAL1 in a circadian manner and promotes the deacetylation and degradation of PER2 [164]. Given the emerging role of NAD+/SIRT1 pathways in fasting diet and anti-aging pathways [165], these results provide important mechanistic insights into the close relationship between circadian rhythms and aging-related pathogenic processes.

\subsection{Heme}

A growing body of evidence indicates that circadian rhythms can also be regulated by additional redox-active compounds including heme, its breakdown product $\mathrm{CO}$ gas, as well as NO gas. Heme is an iron-containing porphyrin that has several functions, from oxygen transport to electron transfer and catalysis [166]. In early studies, heme was shown to be rhythmically controlled by cyclic synthesis and degradation, mediated by the circadian-regulated enzymes aminolevulinic acid synthase (ALAS1) and heme oxygenase (HO), respectively [167]. It has also been described to be a ligand of REV-ERB $\alpha$ that represses its transcriptional activity by recruiting co-repressors, thereby coordinating circadian and metabolic pathways $[168,169]$. Heme has also been shown to bind to CLOCK or NPAS2 in vitro, mediating the reduced DNA binding of CLOCK/NPAS2:BMAL1, induced by carbon-monoxide (CO) $[170,171]$. Furthermore, a structural and functional study revealed that heme directly binds to CLOCK protein and disrupts the binding of this circadian activator to its E-box DNA target [172]. These findings nicely correspond with a previous functional study showing that heme dose-dependently and reversibly dampens luminescence rhythms in SCN explants from mice expressing an E-box-containing Per2 promoter-driven luciferase (PER2::LUC) reporter [173].

\subsection{Carbon Monoxide (CO)}

Carbon monoxide ( $\mathrm{CO}$ ) and nitric oxide (NO; see below) are gasotransmitters, endogenously generated, membrane-permeable gasses that impact on cellular signaling pathways. In addition to the role of heme in molecular clock function, Klemz et al. recently reported that $\mathrm{CO}$, a natural by-product gas of heme breakdown, suppresses circadian transcription by attenuating CLOCK-BMAL1 binding to target promoters [174]. Conversely, suppression of $\mathrm{CO}$ production was shown to lead to a global upregulation of circadian gene expression and dysregulated glucose metabolism in mouse hepatocytes [174]. Further analysis showed that pharmacological inhibition or genetic depletion of CO-producing heme oxygenases abrogated normal daily cycles in mammalian cells and in Drosophila (fruit flies), suggesting the requirement for daily cycles of $\mathrm{CO}$ to maintain normal circadian rhythms as well as circadian metabolic outputs [174]. The crucial role of CO in circadian rhythms was further confirmed by a later study showing that selective removal of endogenous $\mathrm{CO}$ by administration of hemoCD1, a highly selective CO scavenger, considerably disrupts CLOCK/NPAS2:BMAL1-dependent rhythmic expression of clock genes in mice [175]. Notably, against the common notion of $\mathrm{CO}$ as a metabolic waste product or toxic poison, this circadian gasotransmitter is becoming an emerging therapeutic target for neuroprotection as well as for treating inflammation, cancer, and sickle cell disease [176,177]. In line with this notion, recent studies have shown that $\mathrm{CO}$ exerts a protective effect on neuronal or ischemic injuries by preserving or enhancing circadian rhythms [178,179].

\subsection{Nitric Oxide (NO)}

As a gasotransmitter synthesized by three enzymes (endothelial, inducible, and neuronal nitric oxide synthases) with varying patterns of tissue-specific expression, NO plays an important role as a protective mediator in the cardiovascular and neurovascular systems [180]. Accumulating evidence suggests that NO is a rhythmically controlled gas molecule that can influence circadian rhythms and diseases. In an early study, circadian variation of eNOS activity and cytosolic protein content was reported in several regions of the rodent brain, such as the cerebellum, brainstem, hypothalamus, and hippocampus, that reach acrophase in the active phase [181]. A later study using in vivo microdialysis showed 
that the extracellular concentration of nitrite $\left(\mathrm{NO}_{2}{ }^{-}\right)$, an oxidized product of $\mathrm{NO}$, exhibited persistent circadian rhythms in the dorsal rat SCN under constant darkness as well as during the LD cycle [182]. This suggests that the endogenous rhythm of NO is regulated independently of photic inputs into the SCN. Indeed, in other studies, the endogenous rhythms of eNOS activity in brain, kidney, testis, and lungs, as well as plasma NO levels, displayed $24 \mathrm{~h}$ rhythms under either LD or continuously lit conditions $[183,184]$. Furthermore, the rhythms of eNOS activity and expression were shown in the hippocampus of the pigeon and in isolated chick choroid, suggesting the evolutionary conservation of $\mathrm{NO}$ as a circadian-regulated signaling molecule [185].

The functional relevance of NO synthesized by endothelial nitric oxide synthase (eNOS) in circadian rhythmicity was shown in a recent study reporting that a time-of-day variation in vascular smooth muscle contractility occurs in phase with the daily fluctuation of $e N O S$ mRNA levels [186]. Further evidence has also suggested a circadian mechanism underlying the NO cycle. Interestingly, leptin, a hormone that mainly acts to regulate appetite and fat storage, was found to cycle in phase with the NO cycle in adipocytes and also stimulated NO release from the hypothalamus and anterior pituitary gland in rats [187]. This data suggests that the circadian release of leptin contributes to the systemic NO cycle. In a later study, it was shown that mutation of the Per2 gene in mice led to aortic endothelial dysfunction involving mechanisms that included the decreased production of NO [188]. In addition, Bmal1 KO resulted in uncoupling of eNOS from its cofactor tetrahydrobiopterin (BH4) and increased superoxide at the expense of $\mathrm{NO}$, contributing to endothelial dysfunction [189], indicating the physiological importance of clock genes in the regulation of NO. In line with the animal studies, a study in humans showed day-night variations in blood levels of NO in both healthy adults and subjects with type II diabetes; however, higher concentrations of NO were observed in the diabetic subjects compared with the healthy ones [190]. Thus, it was reasoned that higher concentrations of NO may result in increased vascular wall uptake of lipoproteins in diabetic subjects, who are at greater risk than healthy subjects for developing diffuse atherosclerosis [190].

Despite the conserved NO rhythmicity, it is controversial whether NO can regulate circadian rhythms. Genetic knockout model studies showed no significant changes in phase-shift locomotor activity and circadian blood pressure in $\mathrm{eNOS}^{-/-}$mice compared with wild-type mice under LD or constantly dark conditions [191,192], suggesting that eNOS may not be critical for photic entrainment in mice. Upregulation of another of the three NOS isoforms may have compensated for eNOS deficiency in this model. However, a later study showed that NO upregulated the circadian expression of Per genes via cAMP response element- dependent and E-box enhancer element-dependent pathways [193]. This is reminiscent of previous studies showing that exogenous NO potentiated photic phase shifts of circadian rhythms, while the infusion of a NOS inhibitor disrupted the rhythms of water intake [194]. Notably, along with impaired clock gene expression and circadian variation in blood pressure, eNOS activity was shown to be markedly decreased during the daytime in aged animals; however, treatment with an NO donor significantly improved these impairments [193]. Considering the emerging role of NO as an antioxidant and antiaging molecule, this data suggests that NO can prevent or mitigate pathological disruption of circadian rhythms. Related to this, a recent Drosophila model study showed that fly mutants lacking NOS had behavioral arrhythmia in constant darkness, although molecular clocks in the main pacemaker neurons were unaffected [195]. The rhythm disruptive phenotypes of these mutants were found to be due, in part, to malformation of the neurites of small ventral lateral clock neurons (s-LNvs), the main circadian pacemaking cells in the fly brain [195]. This study also identified perineurial glia, one of the two glial subtypes that form the blood-brain barrier, as the major source of NO regulating circadian locomotor output [195]. Taken together, these findings suggest an important role for NO as a systemic signaling molecule in the normal maintenance of circadian physiology and behavior. 


\subsection{Oxygen $\left(\mathrm{O}_{2}\right)$}

Similar to $\mathrm{CO}$, low oxygen (hypoxia) has been suggested as a time cue for entraining molecular clocks. Hypoxia-inducible transcription factors (HIFs), which respond to low oxygen levels and induce its re-supply, interact with BMAL1 via their shared dimerization domains and DNA-binding motifs to mediate the cross-talk between the circadian and hypoxia signaling pathways [196]. In mouse brain, it was shown that hypoxia induces the expression of the circadian genes Per1 and Clock [197]. In subsequent human studies, hypoxia was shown to alter the circadian oscillation of multiple physiological processes, such as body temperature, metabolic rate, cortisol, and melatonin release, leading to sleep disturbances [198-200]. Recently, Adamovich and colleagues documented daily rhythms of tissue oxygenation and oxygen consumption and showed that oxygen cycles, as well as hypoxic conditions, reset cellular and behavioral rhythms in an HIF1 $\alpha$-dependent manner [201,202]. Thus, the authors suggested that oxygen, via HIF1 $\alpha$ activation, is a resetting cue for circadian clocks and proposed oxygen modulation as a therapy for jet lag. In this regard, since oxygen delivery has been implemented as an effective therapy for patients with COVID-19 pneumonia [203], it would be interesting to take into account the potential effects of oxygen treatment on circadian physiology and disease outcomes [204].

\subsection{Carbon Dioxide $\left(\mathrm{CO}_{2}\right)$}

Notably, Adamovich and colleagues recently showed that the daily rhythms of carbon dioxide $\left(\mathrm{CO}_{2}\right)$ release and oxygen consumption are tightly coupled and circadian clock-controlled, and that time-restricted feeding restores their altered rhythmicity in the clock-deficient mice [201]. Interestingly, further results showed that oxygen rhythms were dominated by activity, while $\mathrm{CO}_{2}$ oscillations were shifted and aligned with food intake [201]. Moreover, changes in $\mathrm{CO}_{2}$ levels altered clock gene expression and phase-shifted the circadian rhythms [201]. Collectively, these results suggest that $\mathrm{CO}_{2}$ rhythms is not only feeding-regulated but also mediates phase resetting of peripheral clocks upon feeding.

\subsection{Hydrogen Peroxide $\left(\mathrm{H}_{2} \mathrm{O}_{2}\right)$}

Emerging studies have suggested that hydrogen peroxide $\left(\mathrm{H}_{2} \mathrm{O}_{2}\right)$ is also a circadian time cue. $\mathrm{H}_{2} \mathrm{O}_{2}$ is an oxidizing agent through its easy release of a single oxygen atom, which is very reactive and toxic to most living organisms, that occurs as a consequence of the oxidation of proteins, membrane lipids, and DNA. In eukaryotic species, $\mathrm{H}_{2} \mathrm{O}_{2}$ is produced as a by-product of oxygen combustion in mitochondria and is the most stable and diffusible of the reactive oxygen species (ROS) [205]. In the cyanobacterium Microcystis aeruginosa, $\mathrm{H}_{2} \mathrm{O}_{2}$ was found to alter the expression rhythms of circadian clock and metabolic genes during the LD cycle [206]. Another study in Drosophila showed that $\mathrm{H}_{2} \mathrm{O}_{2}$ stimulates activity and alters daily locomotor rhythms, suggesting its role as a systemic circadian cue [207]. In line with these studies, a recent study by Fei Pei and colleagues showed that $\mathrm{H}_{2} \mathrm{O}_{2}$ exhibits cell-autonomous rhythms that induce periodic oxidation of the CLOCK protein as well as heterodimerization of CLOCK with BMAL1 followed by DNA binding, thus enhancing the amplitude of cyclic gene expression that affects the daily rhythms of behavior in mice [208]. This evidence suggests that $\mathrm{H}_{2} \mathrm{O}_{2}$ acts as a potent timing signal by directly interacting with the core clock machinery, thus mediating the close connection of daily redox and circadian cycles. Notably, multiple studies have shown that ROS levels are elevated and increase the severity of several diseases with genetic (e.g., Bmal1 KO), environmental (e.g., sleep deprivation, forced chronic jet lag, mistimed feeding, alcohol intake, psycho-social stress, etc.), or pathological (e.g., aging, cancer) disruption of the circadian clock [98,209-211]. Beyond the roles of ROS as prime modulators of cellular, metabolic, and immune dysfunctions, these findings provide important mechanistic insights into how ROS act as direct core clock-controlling molecules, mediating the vicious cycle between circadian disruption and disease processes. 


\subsection{Hydrogen Sulfide $\left(\mathrm{H}_{2} \mathrm{~S}\right)$}

A growing body of evidence suggests that another gasotransmitter, hydrogen sulfide $\left(\mathrm{H}_{2} \mathrm{~S}\right)$, is a potential circadian timing modulator. $\mathrm{H}_{2} \mathrm{~S}$ is a gas that is generated endogenously by cystathionine $\beta$-synthase (CBS), cystathionine $\gamma$-lyase (CSE), and 3-mercaptopyruvate sulfurtransferase (MPST) [212], and serves as a stimulator of electron transport in mammalian mitochondria by acting as an electron donor. Though previously known only as a toxic gas and environmental hazard, it has been demonstrated that $\mathrm{H}_{2} \mathrm{~S}$ mediates a wide range of physiological processes, including blood vessel relaxation, cardioprotection, neurotransmission, neuroprotection, and insulin secretion $[213,214]$. Interestingly, it has been reported that exogenous $\mathrm{H}_{2} \mathrm{~S}$ has a protective effect on maintaining the circadian rhythm of clock genes in isolated hepatocytes by changing the NAD+/NADH ratio and enhancing the activity of SIRT1 [215]. However, a recent study showed that elevating $\mathrm{H}_{2} \mathrm{~S}$ levels using GYY4137, an exogenous $\mathrm{H}_{2} \mathrm{~S}$ donor, decreased Per2 expression, whereas depleting $\mathrm{H}_{2} \mathrm{~S}$ by pharmacological inhibition of CBS increased the general expression and dynamics of several clock genes in serum-shocked NIH3T3 cells, suggesting that the $\mathrm{CBS} / \mathrm{H}_{2} \mathrm{~S}$ pathway may participate in circadian clock regulation. Related to this, it was recently reported that CBS physically interacts with CRY1, augmenting CRY1-mediated repression of the CLOCK:BMAL1 complex and shortening the circadian period in cells, while CRY1 stabilizes CBS enzymatic function. Thus, multiple mechanisms contribute to the bidirectional regulation of the $\mathrm{CBS} / \mathrm{H}_{2} \mathrm{~S}$ pathway and the circadian clock. On the other hand, another study showed that plasma $\mathrm{H}_{2} \mathrm{~S}$ concentration exhibits diurnal fluctuations, along with time of day MPST activity and $\mathrm{H}_{2} \mathrm{O}_{2}$ concentration, in mice [216]. The diurnal $\mathrm{H}_{2} \mathrm{~S}$ fluctuation appeared to be $\mathrm{H}_{2} \mathrm{O}_{2}$-dependent because it disappeared when the mice were treated with dithiothreitol (DTT), a reductant used to clean ROS [216]. Thus, it was postulated that the rhythmic changes in redox-sensitive MPST activity modulated by plasma $\mathrm{H}_{2} \mathrm{O}_{2}$ oscillation led to the diurnal fluctuations of plasma $\mathrm{H}_{2} \mathrm{~S}$ [216] However, a recent study showed that $\mathrm{H}_{2} \mathrm{~S}$ increases the production of NADPH oxidase-dependent $\mathrm{H}_{2} \mathrm{O}_{2}$, suggesting a dynamic regulatory relationship between $\mathrm{H}_{2} \mathrm{~S}$ and $\mathrm{H}_{2} \mathrm{O}_{2}$ synthesis/activity cycles [217]. Notably, increasing evidence has shown that treatment with exogenous $\mathrm{H}_{2} \mathrm{~S}$ prevents or reverses aging and age-related pathologies $[165,218]$. In line with this data, it has been reported that $\mathrm{H}_{2} \mathrm{~S}$ restores the diurnal variation in cardiac function that is disrupted in aging mice by reducing oxidative stress [219]. Taken together, these results suggest a potential clock-modulatory role of $\mathrm{H}_{2} \mathrm{~S}$ that can be leveraged to improve both circadian rhythms and disorders.

\subsection{Minerals and Metal Ions}

Minerals and metal ions are fundamental elements that can mediate multiple physiological processes including neural, metabolic, and immune functions. Dysregulated production of or environmental exposure to certain mineral or metal ion species can cause sleep and psychiatric disturbances, metabolic and endocrine disorders, or neurological degeneration [93]. It has been well-documented that several ions display evolutionarily conserved rhythms in cellular concentration and transport across several species [220]. For example, calcium $\left(\mathrm{Ca}^{2+}\right)$ has robust circadian and diurnal rhythms in plants, flies, and mice to modulate temporal physiology and behaviors [221-224]. Notably, an increasing number of studies in the plant Arabidopsis thaliana report that intracellular transport of copper $\left(\mathrm{Cu}^{2+}\right)$ ion is clock-controlled, and, in turn, endogenous $\mathrm{Cu}^{2+}$ cycles as well as exogenous $\mathrm{Cu}^{2+}$ influence the circadian clock by regulating the expression of core clock components and clock output genes [220,225-227]. These results suggest the ubiquitous nature of reciprocal feedback regulation between the circadian clock and rhythmic ion cycles. Likewise, in early human studies, several metal ions, including $\mathrm{Cu}^{2+}$, zinc, lead, and mercury, were observed to exhibit circadian variation in plasma and urine [228-230]. These rhythms were, in part, attributed to circadian renal functions such as daily rhythms in glomerular filtration and reabsorption by the distal tubule and collecting duct during the night and morning hours [230]. In line with this, circadian profiles of calcium (Ca), magnesium (Mg), iron (Fe), 
$\mathrm{Cu}^{2+}$, zinc $(\mathrm{Zn})$, lead $(\mathrm{Pb})$, cadmium $(\mathrm{Cd})$, cobalt $(\mathrm{Co})$, chromium $(\mathrm{Cr})$, and nickel $(\mathrm{Ni})$ were observed in the urine of healthy, middle-aged men [231].

The functional relevance of ion cycles in circadian physiology, particularly in the brain, has been further suggested by recent animal studies. Using fly and mouse models, Flourakis et al. reported conserved ion cycles for circadian clock control of membrane excitability [232]. Their results showed that during the morning/day, sodium influx mediated by the sodium leak channel (NALCN) was elevated while resting potassium $\left(\mathrm{K}^{+}\right)$currents were reduced, depolarizing neurons to promote elevated firing rates. Conversely, sodium leak was low and resting $\mathrm{K}^{+}$ion currents were elevated during the evening/night, hyperpolarizing cells, and suppressing firing rates [232]. Moreover, the rhythmic NA/NALCN current in fly and mouse clock neurons was shown to be driven by clock-controlled expression of NCA localization factor 1 (Nlf-1), a gene previously known to regulate neuronal excitability and rhythmic behaviors in C. elegans and mice [232,233]. A similar, subsequent study showed that anti-phasic changes in the composition of brain interstitial ions $\left(\mathrm{K}^{+}\right.$ versus $\mathrm{Ca}^{2+}, \mathrm{Mg}^{2+}$ ) control the sleep-wake cycle [234]. Indeed, in vivo recording in mouse brain showed that arousal was linked to the elevation of interstitial $\mathrm{K}^{+}$levels concomitant with decreases in interstitial $\mathrm{Ca}^{2+}$ and $\mathrm{Mg}^{2+}$ levels as well as extracellular volume. Conversely, natural sleep and anesthesia reduced $\mathrm{K}^{+}$levels while increasing $\mathrm{Ca}^{2+}$ and $\mathrm{Mg}^{2+}$ levels along with extracellular volume [234].

On the other hand, accumulating evidence suggests that rhythmic changes in ion levels can directly influence circadian physiology and behavior. For example, Kim and colleagues showed, using in vitro cellular models, that $\mathrm{Ca}^{2+}$-dependent signaling pathways mediate the resetting of the circadian clock by immediate early induction of Per genes via rapid CLOCK/BMAL1 heterodimerization and nuclear localization $[28,235]$. This partly explains how intracellular $\mathrm{Ca}^{2+}$ generates and maintains circadian rhythms in the mouse SCN and behavioral rhythms in flies [224,236-238]. As with $\mathrm{Ca}^{2+}, \mathrm{Cu}^{2+}$ was also found to induce nighttime phase shifts of the SCN clock in a mitogen-activated protein kinase (MAPK)-dependent manner [239]. In line with this, Feeney et al. showed that intracellular $\mathrm{Mg}^{2+}$ exhibits robust cell-intrinsic circadian rhythms and acts as a cell-autonomous timekeeping factor to determine circadian rhythms of gene expression, ATP-dependent energy expenditure, and mTOR-mediated translation in both a human cell line and a unicellular alga [240]. Conserved circadian function of $\mathrm{Mg}^{2+}$ was further suggested in recent studies by the Sehgal group that reported that the magnesium cycle can mediate circadian rhythms in the permeability of the blood-brain barrier (BBB) and xenobiotic efflux in flies, mice, and humans [241-243].

In addition to their rhythmic neuro-modulatory functions, ionic species have been shown to regulate processes in a variety of other body systems. A recent study using electrophysiological and pharmacological approaches revealed that rhythmic $\mathrm{K}^{+}$transport regulates the circadian clock in human red blood cells in the absence of conventional transcription cycles [244]. Interestingly, it has also been suggested that some dietary ions can reset circadian rhythms, influencing metabolic health and disease treatment. For example, selenium (Se), specifically known for its anti-oxidant, anti-inflammatory, and anti-viral activities, was shown to upregulate the expression of Bmal1 in mice, leading to a significant increase in the resistance to toxicity induced by chemotherapeutic agents [245]. Moreover, another study showed that dietary iron controls circadian glucose metabolism by regulating heme-mediated interaction of REV-ERB $\alpha$ with its corepressor nuclear receptor corepressor 1 (NCOR) [246]. In more recent work, Gizowski et al. reported that systemic injection of salt $(\mathrm{NaCl})$ solution can reset the $\mathrm{SCN}$ clock via salt-sensitive neurons in sodium-sensing organum vasculosum lamina terminalis (OVLT) in the brain, inducing phase-advance in circadian locomotor rhythms in mice [247]. Overall, these findings underscore the broad molecular and systemic impacts of nutrient ions on circadian rhythms and diseases. 


\section{Conclusions}

In recent decades, extensive chronobiological research has expanded our understanding of the functional roles and mechanisms of the circadian clockwork in human health and diseases. Thus, research trends in chronobiology have undergone a paradigm shift in many ways, particularly changing from hierarchical models to more integrated ones for understanding the circadian clock mechanism. In this regard, the overall evidence points to bidirectional crosstalk between transcriptional and metabolic rhythms, neuronal and glial clocks, SCN and non-SCN clocks, as well as brain and peripheral clocks (Figures 1 and 2). Our growing knowledge of the interactive nature of clock regulatory systems is expected to not only diversify our understanding of circadian physiology and pathophysiology but also increase our capacity to harness chronobiological knowledge to improve the prevention and treatment of multiple circadian-related disorders.

Author Contributions: Conceptualization, Y.L.; writing—original draft preparation, Y.L.; writing—review and editing, Y.L. and J.P.W.; visualization, Y.L.; supervision, Y.L. All authors have read and agreed to the published version of the manuscript.

Funding: This work was supported by the Elson S. Floyd College of Medicine to Y.L. and The APC was funded by start-up fund to Y.L.

Institutional Review Board Statement: Not applicable.

Informed Consent Statement: Not applicable.

Data Availability Statement: No new data were created or analyzed in this study.

Conflicts of Interest: The authors declare no conflict of interest.

\section{References}

1. Dunlap, J.C. Molecular bases for circadian clocks. Cell 1999, 96, 271-290. [CrossRef]

2. Bass, J.; Lazar, M.A. Circadian time signatures of fitness and disease. Science 2016, 354, 994-999. [CrossRef] [PubMed]

3. Chaix, A.; Zarrinpar, A.; Panda, S. The circadian coordination of cell biology. J. Cell Biol. 2016, 215, 15-25. [CrossRef]

4. Kalmbach, D.A.; Schneider, L.D.; Cheung, J.; Bertrand, S.J.; Kariharan, T.; Pack, A.I.; Gehrman, P.R. Genetic Basis of Chronotype in Humans: Insights From Three Landmark GWAS. Sleep 2017, 40, zsw048. [CrossRef]

5. Refinetti, R.; Wassmer, T.; Basu, P.; Cherukalady, R.; Pandey, V.K.; Singaravel, M.; Giannetto, C.; Piccione, G. Variability of behavioral chronotypes of 16 mammalian species under controlled conditions. Physiol. Behav. 2016, 161, 53-59. [CrossRef] [PubMed]

6. Bloch, G.; Barnes, B.M.; Gerkema, M.P.; Helm, B. Animal activity around the clock with no overt circadian rhythms: Patterns, mechanisms and adaptive value. Proc. Biol. Sci. 2013, 280, 20130019. [CrossRef]

7. Dominoni, D.M.; Borniger, J.C.; Nelson, R.J. Light at night, clocks and health: From humans to wild organisms. Biol. Lett. 2016, 12, 20160015. [CrossRef]

8. Cederroth, C.R.; Albrecht, U.; Bass, J.; Brown, S.A.; Dyhrfjeld-Johnsen, J.; Gachon, F.; Green, C.B.; Hastings, M.H.; Helfrich-Förster, C.; Hogenesch, J.B.; et al. Medicine in the Fourth Dimension. Cell Metab. 2019, 30, 238-250. [CrossRef] [PubMed]

9. Patke, A.; Young, M.W.; Axelrod, S. Molecular mechanisms and physiological importance of circadian rhythms. Nat. Rev. Mol. Cell. Biol. 2020, 21, 67-84. [CrossRef]

10. Lee, Y.; Field, J.M.; Sehgal, A. Circadian Rhythms, Disease and Chronotherapy. J. Biol. Rhythms 2021, 7487304211044301. [CrossRef]

11. Logan, R.W.; McClung, C.A. Rhythms of life: Circadian disruption and brain disorders across the lifespan. Nat. Rev. Neurosci. 2019, 20, 49-65. [CrossRef]

12. Scheiermann, C.; Gibbs, J.; Ince, L.; Loudon, A. Clocking in to immunity. Nat. Rev. Immunol. 2018, 18, 423-437. [CrossRef] [PubMed]

13. Segers, A.; Depoortere, I. Circadian clocks in the digestive system. Nat. Rev. Gastroenterol. Hepatol. 2021, 18, 239-251. [CrossRef] [PubMed]

14. Masri, S.; Sassone-Corsi, P. The emerging link between cancer, metabolism, and circadian rhythms. Nat. Med. 2018, 24, 1795-1803. [CrossRef]

15. Aiello, I.; Fedele, M.L.M.; Roman, F.; Marpegan, L.; Caldart, C.; Chiesa, J.J.; Golombek, D.A.; Finkielstein, C.V.; Paladino, N. Circadian disruption promotes tumor-immune microenvironment remodeling favoring tumor cell proliferation. Sci. Adv. 2020, 6, eaaz4530. [CrossRef] [PubMed]

16. Hadadi, E.; Taylor, W.; Li, X.M.; Aslan, Y.; Villote, M.; Riviere, J.; Duvallet, G.; Auriau, C.; Dulong, S.; Raymond-Letron, I.; et al. Chronic circadian disruption modulates breast cancer stemness and immune microenvironment to drive metastasis in mice. Nat. Commun. 2020, 11, 3193. [CrossRef] 
17. Mattis, J.; Sehgal, A. Circadian Rhythms, Sleep, and Disorders of Aging. Trends Endocrinol. Metab. 2016, 27, 192-203. [CrossRef]

18. Shafi, A.A.; McNair, C.M.; McCann, J.J.; Alshalalfa, M.; Shostak, A.; Severson, T.M.; Zhu, Y.; Bergman, A.; Gordon, N.; Mandigo, A.C.; et al. The circadian cryptochrome, CRY1, is a pro-tumorigenic factor that rhythmically modulates DNA repair. Nat. Commun. 2021, 12, 401. [CrossRef]

19. Lee, Y.; Lahens, N.F.; Zhang, S.; Bedont, J.; Field, J.M.; Sehgal, A. G1/S cell cycle regulators mediate effects of circadian dysregulation on tumor growth and provide targets for timed anticancer treatment. PLoS Biol. 2019, 17, e3000228. [CrossRef]

20. Lee, Y.; Fong, S.Y.; Shon, J.; Zhang, S.L.; Brooks, R.; Lahens, N.F.; Chen, D.; Dang, C.V.; Field, J.M.; Sehgal, A. Time-of-day specificity of anticancer drugs may be mediated by circadian regulation of the cell cycle. Sci. Adv. 2021, 7, eabd2645. [CrossRef]

21. Diallo, A.B.; Coiffard, B.; Leone, M.; Mezouar, S.; Mege, J.L. For Whom the Clock Ticks: Clinical Chronobiology for Infectious Diseases. Front. Immunol. 2020, 11, 1457. [CrossRef]

22. Gabriel, B.M.; Zierath, J.R. Circadian rhythms and exercise-Re-setting the clock in metabolic disease. Nat. Rev. Endocrinol. 2019, 15, 197-206. [CrossRef] [PubMed]

23. Lewis, P.; Oster, H.; Korf, H.W.; Foster, R.G.; Erren, T.C. Food as a circadian time cue-Evidence from human studies. Nat. Rev. Endocrinol. 2020, 16, 213-223. [CrossRef] [PubMed]

24. Johnson, C.H.; Zhao, C.; Xu, Y.; Mori, T. Timing the day: What makes bacterial clocks tick? Nat. Rev. Microbiol. 2017, 15, $232-242$. [CrossRef]

25. Takahashi, J.S. Transcriptional architecture of the mammalian circadian clock. Nat. Rev. Genet. 2017, 18, 164-179. [CrossRef] [PubMed]

26. Koronowski, K.B.; Sassone-Corsi, P. Communicating clocks shape circadian homeostasis. Science 2021, 371, eabd0951. [CrossRef]

27. Anafi, R.C.; Lee, Y.; Sato, T.K.; Venkataraman, A.; Ramanathan, C.; Kavakli, I.H.; Hughes, M.E.; Baggs, J.E.; Growe, J.; Liu, A.C.; et al. Machine learning helps identify CHRONO as a circadian clock component. PLoS Biol. 2014, 12, e1001840. [CrossRef]

28. Lee, Y.; Lee, J.; Kwon, I.; Nakajima, Y.; Ohmiya, Y.; Son, G.H.; Lee, K.H.; Kim, K. Coactivation of the CLOCK-BMAL1 complex by CBP mediates resetting of the circadian clock. J. Cell Sci. 2010, 123, 3547-3557. [CrossRef]

29. Lee, J.; Lee, Y.; Lee, M.J.; Park, E.; Kang, S.H.; Chung, C.H.; Lee, K.H.; Kim, K. Dual modification of BMAL1 by SUMO2/3 and ubiquitin promotes circadian activation of the CLOCK/BMAL1 complex. Mol. Cell. Biol. 2008, 28, 6056-6065. [CrossRef]

30. Lee, Y.; Shen, Y.; Francey, L.J.; Ramanathan, C.; Sehgal, A.; Liu, A.C.; Hogenesch, J.B. The NRON complex controls circadian clock function through regulated PER and CRY nuclear translocation. Sci. Rep. 2019, 9, 11883. [CrossRef]

31. Lee, Y.; Jang, A.R.; Francey, L.J.; Sehgal, A.; Hogenesch, J.B. KPNB1 mediates PER/CRY nuclear translocation and circadian clock function. eLife 2015, 4, e08647. [CrossRef] [PubMed]

32. Lee, Y.; Chun, S.K.; Kim, K. Sumoylation controls CLOCK-BMAL1-mediated clock resetting via CBP recruitment in nuclear transcriptional foci. Biochim. Biophys. Acta 2015, 1853, 2697-2708. [CrossRef]

33. Korge, S.; Maier, B.; Bruning, F.; Ehrhardt, L.; Korte, T.; Mann, M.; Herrmann, A.; Robles, M.S.; Kramer, A. The non-classical nuclear import carrier Transportin 1 modulates circadian rhythms through its effect on PER1 nuclear localization. PLoS Genet. 2018, 14, e1007189. [CrossRef]

34. Zhang, R.; Lahens, N.F.; Ballance, H.I.; Hughes, M.E.; Hogenesch, J.B. A circadian gene expression atlas in mammals: Implications for biology and medicine. Proc. Natl. Acad. Sci. USA 2014, 111, 16219-16224. [CrossRef]

35. Mure, L.S.; Le, H.D.; Benegiamo, G.; Chang, M.W.; Rios, L.; Jillani, N.; Ngotho, M.; Kariuki, T.; Dkhissi-Benyahya, O.; Cooper, H.M.; et al. Diurnal transcriptome atlas of a primate across major neural and peripheral tissues. Science 2018, 359, eaao0318. [CrossRef] [PubMed]

36. Ruben, M.D.; Wu, G.; Smith, D.F.; Schmidt, R.E.; Francey, L.J.; Lee, Y.Y.; Anafi, R.C.; Hogenesch, J.B. A database of tissue-specific rhythmically expressed human genes has potential applications in circadian medicine. Sci. Transl. Med. 2018, 10, eaat8806. [CrossRef] [PubMed]

37. Thaiss, C.A.; Zeevi, D.; Levy, M.; Zilberman-Schapira, G.; Suez, J.; Tengeler, A.C.; Abramson, L.; Katz, M.N.; Korem, T.; Zmora, N.; et al. Transkingdom control of microbiota diurnal oscillations promotes metabolic homeostasis. Cell 2014, 159, 514-529. [CrossRef]

38. Dyar, K.A.; Lutter, D.; Artati, A.; Ceglia, N.J.; Liu, Y.; Armenta, D.; Jastroch, M.; Schneider, S.; de Mateo, S.; Cervantes, M.; et al. Atlas of Circadian Metabolism Reveals System-wide Coordination and Communication between Clocks. Cell 2018, 174, 1571-1585.e11. [CrossRef]

39. Solanas, G.; Peixoto, F.O.; Perdiguero, E.; Jardi, M.; Ruiz-Bonilla, V.; Datta, D.; Symeonidi, A.; Castellanos, A.; Welz, P.S.; Caballero, J.M.; et al. Aged Stem Cells Reprogram Their Daily Rhythmic Functions to Adapt to Stress. Cell 2017, 170, 678-692.e20. [CrossRef]

40. Wang, J.; Mauvoisin, D.; Martin, E.; Atger, F.; Galindo, A.N.; Dayon, L.; Sizzano, F.; Palini, A.; Kussmann, M.; Waridel, P.; et al. Nuclear Proteomics Uncovers Diurnal Regulatory Landscapes in Mouse Liver. Cell Metab. 2017, 25, 102-117. [CrossRef] [PubMed]

41. Wang, Y.; Song, L.; Liu, M.; Ge, R.; Zhou, Q.; Liu, W.; Li, R.; Qie, J.; Zhen, B.; Wang, Y.; et al. A proteomics landscape of circadian clock in mouse liver. Nat. Commun. 2018, 9, 1553. [CrossRef] [PubMed]

42. Robles, M.S.; Humphrey, S.J.; Mann, M. Phosphorylation Is a Central Mechanism for Circadian Control of Metabolism and Physiology. Cell Metab. 2017, 25, 118-127. [CrossRef]

43. Chiang, C.K.; Xu, B.; Mehta, N.; Mayne, J.; Sun, W.Y.; Cheng, K.; Ning, Z.; Dong, J.; Zou, H.; Cheng, H.M.; et al. Phosphoproteome Profiling Reveals Circadian Clock Regulation of Posttranslational Modifications in the Murine Hippocampus. Front. Neurol. 2017, 8, 110. [CrossRef] [PubMed] 
44. Noya, S.B.; Colameo, D.; Bruning, F.; Spinnler, A.; Mircsof, D.; Opitz, L.; Mann, M.; Tyagarajan, S.K.; Robles, M.S.; Brown, S.A. The forebrain synaptic transcriptome is organized by clocks but its proteome is driven by sleep. Science 2019, 366, eaav2642. [CrossRef]

45. Malik, D.M.; Paschos, G.K.; Sehgal, A.; Weljie, A.M. Circadian and Sleep Metabolomics Across Species. J. Mol. Biol. 2020, 432, 3578-3610. [CrossRef]

46. Hofman, M.A.; Fliers, E.; Goudsmit, E.; Swaab, D.F. Morphometric analysis of the suprachiasmatic and paraventricular nuclei in the human brain: Sex differences and age-dependent changes. J. Anat. 1988, 160, 127-143. [PubMed]

47. Hofman, M.A.; Swaab, D.F. A brain for all seasons: Cellular and molecular mechanisms of photoperiodic plasticity. Prog. Brain Res. 2002, 138, 255-280. [CrossRef]

48. Hofman, M.A.; Swaab, D.F. Living by the clock: The circadian pacemaker in older people. Ageing Res. Rev. 2006, 5, 33-51. [CrossRef]

49. Harmar, A.J.; Marston, H.M.; Shen, S.; Spratt, C.; West, K.M.; Sheward, W.J.; Morrison, C.F.; Dorin, J.R.; Piggins, H.D.; Reubi, J.C.; et al. The VPAC(2) receptor is essential for circadian function in the mouse suprachiasmatic nuclei. Cell 2002, 109, 497-508. [CrossRef]

50. Brown, T.M.; Colwell, C.S.; Waschek, J.A.; Piggins, H.D. Disrupted neuronal activity rhythms in the suprachiasmatic nuclei of vasoactive intestinal polypeptide-deficient mice. J. Neurophysiol. 2007, 97, 2553-2558. [CrossRef] [PubMed]

51. Yamaguchi, Y.; Suzuki, T.; Mizoro, Y.; Kori, H.; Okada, K.; Chen, Y.; Fustin, J.M.; Yamazaki, F.; Mizuguchi, N.; Zhang, J.; et al. Mice genetically deficient in vasopressin V1a and V1b receptors are resistant to jet lag. Science 2013, 342, 85-90. [CrossRef]

52. Mieda, M.; Ono, D.; Hasegawa, E.; Okamoto, H.; Honma, K.; Honma, S.; Sakurai, T. Cellular clocks in AVP neurons of the SCN are critical for interneuronal coupling regulating circadian behavior rhythm. Neuron 2015, 85, 1103-1116. [CrossRef] [PubMed]

53. Patton, A.P.; Edwards, M.D.; Smyllie, N.J.; Hamnett, R.; Chesham, J.E.; Brancaccio, M.; Maywood, E.S.; Hastings, M.H. The VIP-VPAC2 neuropeptidergic axis is a cellular pacemaking hub of the suprachiasmatic nucleus circadian circuit. Nat. Commun. 2020, 11, 3394. [CrossRef]

54. Todd, W.D.; Venner, A.; Anaclet, C.; Broadhurst, R.Y.; De Luca, R.; Bandaru, S.S.; Issokson, L.; Hablitz, L.M.; Cravetchi, O.; Arrigoni, E.; et al. Suprachiasmatic VIP neurons are required for normal circadian rhythmicity and comprised of molecularly distinct subpopulations. Nat. Commun. 2020, 11, 4410. [CrossRef] [PubMed]

55. Wen, S.; Ma, D.; Zhao, M.; Xie, L.; Wu, Q.; Gou, L.; Zhu, C.; Fan, Y.; Wang, H.; Yan, J. Spatiotemporal single-cell analysis of gene expression in the mouse suprachiasmatic nucleus. Nat. Neurosci. 2020, 23, 456-467. [CrossRef] [PubMed]

56. Park, J.; Zhu, H.; O'Sullivan, S.; Ogunnaike, B.A.; Weaver, D.R.; Schwaber, J.S.; Vadigepalli, R. Single-Cell Transcriptional Analysis Reveals Novel Neuronal Phenotypes and Interaction Networks Involved in the Central Circadian Clock. Front. Neurosci. 2016, 10, 481. [CrossRef]

57. Morris, E.L.; Patton, A.P.; Chesham, J.E.; Crisp, A.; Adamson, A.; Hastings, M.H. Single-cell transcriptomics of suprachiasmatic nuclei reveal a Prokineticin-driven circadian network. EMBO J. 2021, 40, e108614. [CrossRef]

58. Brancaccio, M.; Patton, A.P.; Chesham, J.E.; Maywood, E.S.; Hastings, M.H. Astrocytes Control Circadian Timekeeping in the Suprachiasmatic Nucleus via Glutamatergic Signaling. Neuron 2017, 93, 1420-1435.e5. [CrossRef]

59. Tso, C.F.; Simon, T.; Greenlaw, A.C.; Puri, T.; Mieda, M.; Herzog, E.D. Astrocytes Regulate Daily Rhythms in the Suprachiasmatic Nucleus and Behavior. Curr. Biol. 2017, 27, 1055-1061. [CrossRef] [PubMed]

60. Brancaccio, M.; Edwards, M.D.; Patton, A.P.; Smyllie, N.J.; Chesham, J.E.; Maywood, E.S.; Hastings, M.H. Cell-autonomous clock of astrocytes drives circadian behavior in mammals. Science 2019, 363, 187-192. [CrossRef]

61. Buijs, R.M.; Guzman Ruiz, M.A.; Mendez Hernandez, R.; Rodriguez Cortes, B. The suprachiasmatic nucleus; a responsive clock regulating homeostasis by daily changing the setpoints of physiological parameters. Auton. Neurosci. 2019, 218, 43-50. [CrossRef] [PubMed]

62. Gizowski, C.; Zaelzer, C.; Bourque, C.W. Clock-driven vasopressin neurotransmission mediates anticipatory thirst prior to sleep. Nature 2016, 537, 685-688. [CrossRef] [PubMed]

63. Paul, S.; Hanna, L.; Harding, C.; Hayter, E.A.; Walmsley, L.; Bechtold, D.A.; Brown, T.M. Output from VIP cells of the mammalian central clock regulates daily physiological rhythms. Nat. Commun. 2020,11, 1453. [CrossRef]

64. Collins, B.; Pierre-Ferrer, S.; Muheim, C.; Lukacsovich, D.; Cai, Y.; Spinnler, A.; Herrera, C.G.; Wen, S.; Winterer, J.; Belle, M.D.C.; et al. Circadian VIPergic Neurons of the Suprachiasmatic Nuclei Sculpt the Sleep-Wake Cycle. Neuron 2020, 108, 486-499.e5. [CrossRef] [PubMed]

65. Ishida, A.; Mutoh, T.; Ueyama, T.; Bando, H.; Masubuchi, S.; Nakahara, D.; Tsujimoto, G.; Okamura, H. Light activates the adrenal gland: Timing of gene expression and glucocorticoid release. Cell Metab. 2005, 2, 297-307. [CrossRef] [PubMed]

66. Buijs, R.M.; Kalsbeek, A. Hypothalamic integration of central and peripheral clocks. Nat. Rev. Neurosci. 2001, 2, 521-526. [CrossRef]

67. Russell, G.; Lightman, S. The human stress response. Nat. Rev. Endocrinol. 2019, 15, 525-534. [CrossRef]

68. Buijs, F.N.; León-Mercado, L.; Guzmán-Ruiz, M.; Guerrero-Vargas, N.N.; Romo-Nava, F.; Buijs, R.M. The Circadian System: A Regulatory Feedback Network of Periphery and Brain. Physiology 2016, 31, 170-181. [CrossRef]

69. Firsov, D.; Bonny, O. Circadian rhythms and the kidney. Nat. Rev. Nephrol. 2018, 14, 626-635. [CrossRef]

70. Ikegami, K.; Refetoff, S.; Van Cauter, E.; Yoshimura, T. Interconnection between circadian clocks and thyroid function. Nat. Rev. Endocrinol. 2019, 15, 590-600. [CrossRef] 
71. Stenvers, D.J.; Scheer, F.; Schrauwen, P.; la Fleur, S.E.; Kalsbeek, A. Circadian clocks and insulin resistance. Nat. Rev. Endocrinol. 2019, 15, 75-89. [CrossRef] [PubMed]

72. Challet, E. The circadian regulation of food intake. Nat. Rev. Endocrinol. 2019, 15, 393-405. [CrossRef] [PubMed]

73. Tahara, Y.; Shibata, S. Circadian rhythms of liver physiology and disease: Experimental and clinical evidence. Nat. Rev. Gastroenterol. Hepatol. 2016, 13, 217-226. [CrossRef] [PubMed]

74. Hasegawa, S.; Fukushima, H.; Hosoda, H.; Serita, T.; Ishikawa, R.; Rokukawa, T.; Kawahara-Miki, R.; Zhang, Y.; Ohta, M.; Okada, S.; et al. Hippocampal clock regulates memory retrieval via Dopamine and PKA-induced GluA1 phosphorylation. Nat. Commun. 2019, 10, 5766. [CrossRef]

75. Myung, J.; Schmal, C.; Hong, S.; Tsukizawa, Y.; Rose, P.; Zhang, Y.; Holtzman, M.J.; De Schutter, E.; Herzel, H.; Bordyugov, G.; et al. The choroid plexus is an important circadian clock component. Nat. Commun. 2018, 9, 1062. [CrossRef] [PubMed]

76. Son, G.H.; Chung, S.; Choe, H.K.; Kim, H.D.; Baik, S.M.; Lee, H.; Lee, H.W.; Choi, S.; Sun, W.; Kim, H.; et al. Adrenal peripheral clock controls the autonomous circadian rhythm of glucocorticoid by causing rhythmic steroid production. Proc. Natl. Acad. Sci. USA 2008, 105, 20970-20975. [CrossRef]

77. Myung, J.; Wu, M.Y.; Lee, C.Y.; Rahim, A.R.; Truong, V.H.; Wu, D.; Piggins, H.D.; Wu, M.S. The Kidney Clock Contributes to Timekeeping by the Master Circadian Clock. Int. J. Mol. Sci. 2019, 20, 2765. [CrossRef]

78. Sinturel, F.; Gos, P.; Petrenko, V.; Hagedorn, C.; Kreppel, F.; Storch, K.F.; Knutti, D.; Liani, A.; Weitz, C.; Emmenegger, Y.; et al. Circadian hepatocyte clocks keep synchrony in the absence of a master pacemaker in the suprachiasmatic nucleus or other extrahepatic clocks. Genes Dev. 2021, 35, 329-334. [CrossRef]

79. Bano-Otalora, B.; Piggins, H.D. Contributions of the lateral habenula to circadian timekeeping. Pharmacol. Biochem. Behav. 2017, 162, 46-54. [CrossRef]

80. Van Drunen, R.; Eckel-Mahan, K. Circadian Rhythms of the Hypothalamus: From Function to Physiology. Clocks Sleep 2021, 3 , 189-226. [CrossRef]

81. Antle, M.C.; Mistlberger, R.E. Circadian clock resetting by sleep deprivation without exercise in the Syrian hamster. J. Neurosci. 2000, 20, 9326-9332. [CrossRef]

82. Mendoza, J. Circadian clocks: Setting time by food. J. Neuroendocrinol. 2007, 19, 127-137. [CrossRef]

83. Marchant, E.G.; Mistlberger, R.E. Morphine phase-shifts circadian rhythms in mice: Role of behavioural activation. Neuroreport 1995, 7, 209-212. [CrossRef]

84. Guerrero-Vargas, N.N.; Salgado-Delgado, R.; Basualdo, M.e.C.; García, J.; Guzmán-Ruiz, M.; Carrero, J.C.; Escobar, C.; Buijs, R.M Reciprocal interaction between the suprachiasmatic nucleus and the immune system tunes down the inflammatory response to lipopolysaccharide. J. Neuroimmunol. 2014, 273, 22-30. [CrossRef] [PubMed]

85. Saderi, N.; Salgado-Delgado, R.; Avendaño-Pradel, R.; Basualdo, M.e.C.; Ferri, G.L.; Chávez-Macías, L.; Roblera, J.E.; Escobar, C.; Buijs, R.M. NPY and VGF immunoreactivity increased in the arcuate nucleus, but decreased in the nucleus of the Tractus Solitarius, of type-II diabetic patients. PLoS ONE 2012, 7, e40070. [CrossRef]

86. Buijs, F.N.; Cazarez, F.; Basualdo, M.C.; Scheer, F.A.; Perusquía, M.; Centurion, D.; Buijs, R.M. The suprachiasmatic nucleus is part of a neural feedback circuit adapting blood pressure response. Neuroscience 2014, 266, 197-207. [CrossRef] [PubMed]

87. Shioiri, T.; Takahashi, K.; Yamada, N.; Takahashi, S. Motor activity correlates negatively with free-running period, while positively with serotonin contents in SCN in free-running rats. Physiol. Behav. 1991, 49, 779-786. [CrossRef]

88. Yi, C.X.; van der Vliet, J.; Dai, J.; Yin, G.; Ru, L.; Buijs, R.M. Ventromedial arcuate nucleus communicates peripheral metabolic information to the suprachiasmatic nucleus. Endocrinology 2006, 147, 283-294. [CrossRef] [PubMed]

89. Acosta-Galvan, G.; Yi, C.X.; van der Vliet, J.; Jhamandas, J.H.; Panula, P.; Angeles-Castellanos, M.; Del Carmen Basualdo, M.; Escobar, C.; Buijs, R.M. Interaction between hypothalamic dorsomedial nucleus and the suprachiasmatic nucleus determines intensity of food anticipatory behavior. Proc. Natl. Acad. Sci. USA 2011, 108, 5813-5818. [CrossRef]

90. Thaiss, C.A.; Levy, M.; Korem, T.; Dohnalova, L.; Shapiro, H.; Jaitin, D.A.; David, E.; Winter, D.R.; Gury-BenAri, M.; Tatirovsky, E.; et al. Microbiota Diurnal Rhythmicity Programs Host Transcriptome Oscillations. Cell 2016, 167, 1495-1510.e12. [CrossRef] [PubMed]

91. Buhr, E.D.; Yoo, S.H.; Takahashi, J.S. Temperature as a universal resetting cue for mammalian circadian oscillators. Science 2010, 330, 379-385. [CrossRef] [PubMed]

92. Reinke, H.; Asher, G. Crosstalk between metabolism and circadian clocks. Nat. Rev. Mol. Cell Biol. 2019, 20, 227-241. [CrossRef]

93. Parmalee, N.L.; Aschner, M. Metals and Circadian Rhythms. Adv. Neurotoxicol. 2017, 1, 119-130. [CrossRef]

94. Rey, G.; Valekunja, U.K.; Feeney, K.A.; Wulund, L.; Milev, N.B.; Stangherlin, A.; Ansel-Bollepalli, L.; Velagapudi, V.; O’Neill, J.S.; Reddy, A.B. The Pentose Phosphate Pathway Regulates the Circadian Clock. Cell Metab. 2016, 24, 462-473. [CrossRef]

95. Ch, R.; Rey, G.; Ray, S.; Jha, P.K.; Driscoll, P.C.; Dos Santos, M.S.; Malik, D.M.; Lach, R.; Weljie, A.M.; MacRae, J.I.; et al. Rhythmic glucose metabolism regulates the redox circadian clockwork in human red blood cells. Nat. Commun. 2021, 12, 377. [CrossRef]

96. Papagiannakopoulos, T.; Bauer, M.R.; Davidson, S.M.; Heimann, M.; Subbaraj, L.; Bhutkar, A.; Bartlebaugh, J.; Vander Heiden, M.G.; Jacks, T. Circadian Rhythm Disruption Promotes Lung Tumorigenesis. Cell Metab. 2016, 24, 324-331. [CrossRef] [PubMed]

97. Alvarez, J.D.; Hansen, A.; Ord, T.; Bebas, P.; Chappell, P.E.; Giebultowicz, J.M.; Williams, C.; Moss, S.; Sehgal, A. The circadian clock protein BMAL1 is necessary for fertility and proper testosterone production in mice. J. Biol. Rhythms 2008, 23, 26-36. [CrossRef] 
98. Kondratov, R.V.; Kondratova, A.A.; Gorbacheva, V.Y.; Vykhovanets, O.V.; Antoch, M.P. Early aging and age-related pathologies in mice deficient in BMAL1, the core componentof the circadian clock. Genes Dev. 2006, 20, 1868-1873. [CrossRef]

99. Walker, W.H., 2nd; Walton, J.C.; DeVries, A.C.; Nelson, R.J. Circadian rhythm disruption and mental health. Transl. Psychiatry 2020, 10, 28. [CrossRef]

100. Bishehsari, F.; Voigt, R.M.; Keshavarzian, A. Circadian rhythms and the gut microbiota: From the metabolic syndrome to cancer. Nat. Rev. Endocrinol. 2020, 16, 731-739. [CrossRef] [PubMed]

101. Musiek, E.S.; Lim, M.M.; Yang, G.; Bauer, A.Q.; Qi, L.; Lee, Y.; Roh, J.H.; Ortiz-Gonzalez, X.; Dearborn, J.T.; Culver, J.P.; et al. Circadian clock proteins regulate neuronal redox homeostasis and neurodegeneration. J. Clin. Investig. 2013, 123, 5389-5400. [CrossRef]

102. Lee, Y. Roles of circadian clocks in cancer pathogenesis and treatment. Exp. Mol. Med. 2021, 53, 1529-1538. [CrossRef]

103. Walker, W.H., 2nd; Bumgarner, J.R.; Walton, J.C.; Liu, J.A.; Melendez-Fernandez, O.H.; Nelson, R.J.; DeVries, A.C. Light Pollution and Cancer. Int. J. Mol. Sci. 2020, 21, 9360. [CrossRef] [PubMed]

104. West, A.C.; Smith, L.; Ray, D.W.; Loudon, A.S.I.; Brown, T.M.; Bechtold, D.A. Misalignment with the external light environment drives metabolic and cardiac dysfunction. Nat. Commun. 2017, 8, 417. [CrossRef] [PubMed]

105. Buxton, O.M.; Cain, S.W.; O'Connor, S.P.; Porter, J.H.; Duffy, J.F.; Wang, W.; Czeisler, C.A.; Shea, S.A. Adverse metabolic consequences in humans of prolonged sleep restriction combined with circadian disruption. Sci. Transl. Med. 2012, 4, 129ra143. [CrossRef] [PubMed]

106. Tahkamo, L.; Partonen, T.; Pesonen, A.K. Systematic review of light exposure impact on human circadian rhythm. Chronobiol. Int. 2019, 36, 151-170. [CrossRef]

107. Husse, J.; Zhou, X.; Shostak, A.; Oster, H.; Eichele, G. Synaptotagmin10-Cre, a driver to disrupt clock genes in the SCN. J. Biol. Rhythms 2011, 26, 379-389. [CrossRef] [PubMed]

108. Husse, J.; Leliavski, A.; Tsang, A.H.; Oster, H.; Eichele, G. The light-dark cycle controls peripheral rhythmicity in mice with a genetically ablated suprachiasmatic nucleus clock. FASEB J. 2014, 28, 4950-4960. [CrossRef]

109. Ralph, M.R.; Foster, R.G.; Davis, F.C.; Menaker, M. Transplanted suprachiasmatic nucleus determines circadian period. Science 1990, 247, 975-978. [CrossRef]

110. Schwartz, W.J.; Zimmerman, P. Lesions of the suprachiasmatic nucleus disrupt circadian locomotor rhythms in the mouse. Physiol. Behav. 1991, 49, 1283-1287. [CrossRef]

111. Husse, J.; Eichele, G.; Oster, H. Synchronization of the mammalian circadian timing system: Light can control peripheral clocks independently of the SCN clock: Alternate routes of entrainment optimize the alignment of the body's circadian clock network with external time. BioEssays News Rev. Mol. Cell. Dev. Biol. 2015, 37, 1119-1128. [CrossRef]

112. Izumo, M.; Pejchal, M.; Schook, A.C.; Lange, R.P.; Walisser, J.A.; Sato, T.R.; Wang, X.; Bradfield, C.A.; Takahashi, J.S. Differential effects of light and feeding on circadian organization of peripheral clocks in a forebrain Bmal1 mutant. eLife 2014, 3. [CrossRef]

113. Ding, G.; Li, X.; Hou, X.; Zhou, W.; Gong, Y.; Liu, F.; He, Y.; Song, J.; Wang, J.; Basil, P.; et al. REV-ERB in GABAergic neurons controls diurnal hepatic insulin sensitivity. Nature 2021, e04617. [CrossRef]

114. Yamakawa, G.R.; Basu, P.; Cortese, F.; MacDonnell, J.; Whalley, D.; Smith, V.M.; Antle, M.C. The cholinergic forebrain arousal system acts directly on the circadian pacemaker. Proc. Natl. Acad. Sci. USA 2016, 113, 13498-13503. [CrossRef] [PubMed]

115. Kolbe, I.; Leinweber, B.; Brandenburger, M.; Oster, H. Circadian clock network desynchrony promotes weight gain and alters glucose homeostasis in mice. Mol Metab 2019, 30, 140-151. [CrossRef] [PubMed]

116. Quintela, T.; Albuquerque, T.; Lundkvist, G.; Carmine Belin, A.; Talhada, D.; Goncalves, I.; Carro, E.; Santos, C.R.A. The choroid plexus harbors a circadian oscillator modulated by estrogens. Chronobiol. Int. 2018, 35, 270-279. [CrossRef] [PubMed]

117. Paschos, G.K.; Ibrahim, S.; Song, W.L.; Kunieda, T.; Grant, G.; Reyes, T.M.; Bradfield, C.A.; Vaughan, C.H.; Eiden, M.; Masoodi, M.; et al. Obesity in mice with adipocyte-specific deletion of clock component Arntl. Nat. Med. 2012, 18, 1768-1777. [CrossRef] [PubMed]

118. Chung, S.; Lee, E.J.; Cha, H.K.; Kim, J.; Kim, D.; Son, G.H.; Kim, K. Cooperative roles of the suprachiasmatic nucleus central clock and the adrenal clock in controlling circadian glucocorticoid rhythm. Sci. Rep. 2017, 7, 46404. [CrossRef]

119. Engeland, W.C.; Massman, L.; Mishra, S.; Yoder, J.M.; Leng, S.; Pignatti, E.; Piper, M.E.; Carlone, D.L.; Breault, D.T.; Kofuji, P. The Adrenal Clock Prevents Aberrant Light-Induced Alterations in Circadian Glucocorticoid Rhythms. Endocrinology 2018, 159, 3950-3964. [CrossRef]

120. Lamia, K.A.; Storch, K.F.; Weitz, C.J. Physiological significance of a peripheral tissue circadian clock. Proc. Natl. Acad. Sci. USA 2008, 105, 15172-15177. [CrossRef]

121. Perelis, M.; Marcheva, B.; Ramsey, K.M.; Schipma, M.J.; Hutchison, A.L.; Taguchi, A.; Peek, C.B.; Hong, H.; Huang, W.; Omura, C.; et al. Pancreatic $\beta$ cell enhancers regulate rhythmic transcription of genes controlling insulin secretion. Science 2015, 350, aac4250. [CrossRef]

122. Ehlen, J.C.; Brager, A.J.; Baggs, J.; Pinckney, L.; Gray, C.L.; DeBruyne, J.P.; Esser, K.A.; Takahashi, J.S.; Paul, K.N. Bmal1 function in skeletal muscle regulates sleep. eLife 2017, 6. [CrossRef]

123. Dyar, K.A.; Hubert, M.J.; Mir, A.A.; Ciciliot, S.; Lutter, D.; Greulich, F.; Quagliarini, F.; Kleinert, M.; Fischer, K.; Eichmann, T.O.; et al. Transcriptional programming of lipid and amino acid metabolism by the skeletal muscle circadian clock. PLoS Biol. 2018, 16, e2005886. [CrossRef] [PubMed] 
124. Nikolaeva, S.; Ansermet, C.; Centeno, G.; Pradervand, S.; Bize, V.; Mordasini, D.; Henry, H.; Koesters, R.; Maillard, M.; Bonny, O.; et al. Nephron-Specific Deletion of Circadian Clock Gene Bmal1 Alters the Plasma and Renal Metabolome and Impairs Drug Disposition. J. Am. Soc. Nephrol. 2016, 27, 2997-3004. [CrossRef]

125. Crislip, G.R.; Douma, L.G.; Masten, S.H.; Cheng, K.Y.; Lynch, I.J.; Johnston, J.G.; Barral, D.; Glasford, K.B.; Holzworth, M.R.; Verlander, J.W.; et al. Differences in renal BMAL1 contribution to Na. Am. J. Physiol. Renal. Physiol. 2020, 318, F1463-F1477. [CrossRef]

126. Yu, F.; Wang, Z.; Zhang, T.; Chen, X.; Xu, H.; Wang, F.; Guo, L.; Chen, M.; Liu, K.; Wu, B. Deficiency of intestinal Bmal1 prevents obesity induced by high-fat feeding. Nat. Commun. 2021, 12, 5323. [CrossRef] [PubMed]

127. Young, M.E.; Brewer, R.A.; Peliciari-Garcia, R.A.; Collins, H.E.; He, L.; Birky, T.L.; Peden, B.W.; Thompson, E.G.; Ammons, B.J.; Bray, M.S.; et al. Cardiomyocyte-specific BMAL1 plays critical roles in metabolism, signaling, and maintenance of contractile function of the heart. J. Biol. Rhythms 2014, 29, 257-276. [CrossRef] [PubMed]

128. Ingle, K.A.; Kain, V.; Goel, M.; Prabhu, S.D.; Young, M.E.; Halade, G.V. Cardiomyocyte-specific Bmal1 deletion in mice triggers diastolic dysfunction, extracellular matrix response, and impaired resolution of inflammation. Am. J. Physiol. Heart Circ. Physiol. 2015, 309, H1827-H1836. [CrossRef]

129. Moore, R.Y.; Eichler, V.B. Loss of a circadian adrenal corticosterone rhythm following suprachiasmatic lesions in the rat. Brain Res. 1972, 42, 201-206. [CrossRef]

130. Oster, H.; Damerow, S.; Kiessling, S.; Jakubcakova, V.; Abraham, D.; Tian, J.; Hoffmann, M.W.; Eichele, G. The circadian rhythm of glucocorticoids is regulated by a gating mechanism residing in the adrenal cortical clock. Cell Metab. 2006, 4, 163-173. [CrossRef]

131. Cho, H.; Zhao, X.; Hatori, M.; Yu, R.T.; Barish, G.D.; Lam, M.T.; Chong, L.W.; DiTacchio, L.; Atkins, A.R.; Glass, C.K.; et al. Regulation of circadian behaviour and metabolism by REV-ERB-alpha and REV-ERB-beta. Nature 2012, 485, 123-127. [CrossRef] [PubMed]

132. Bugge, A.; Feng, D.; Everett, L.J.; Briggs, E.R.; Mullican, S.E.; Wang, F.; Jager, J.; Lazar, M.A. Rev-erbalpha and Rev-erbbeta coordinately protect the circadian clock and normal metabolic function. Genes Dev. 2012, 26, 657-667. [CrossRef]

133. Guan, D.; Xiong, Y.; Trinh, T.M.; Xiao, Y.; Hu, W.; Jiang, C.; Dierickx, P.; Jang, C.; Rabinowitz, J.D.; Lazar, M.A. The hepatocyte clock and feeding control chronophysiology of multiple liver cell types. Science 2020, 369, 1388-1394. [CrossRef]

134. Tsang, A.H.; Koch, C.E.; Kiehn, J.T.; Schmidt, C.X.; Oster, H. An adipokine feedback regulating diurnal food intake rhythms in mice. eLife 2020, 9, e55388. [CrossRef] [PubMed]

135. Calvani, M.; Scarfone, A.; Granato, L.; Mora, E.V.; Nanni, G.; Castagneto, M.; Greco, A.V.; Manco, M.; Mingrone, G. Restoration of adiponectin pulsatility in severely obese subjects after weight loss. Diabetes 2004, 53, 939-947. [CrossRef] [PubMed]

136. Yildiz, B.O.; Suchard, M.A.; Wong, M.L.; McCann, S.M.; Licinio, J. Alterations in the dynamics of circulating ghrelin, adiponectin, and leptin in human obesity. Proc. Natl. Acad. Sci. USA 2004, 101, 10434-10439. [CrossRef]

137. Crosby, P.; Hamnett, R.; Putker, M.; Hoyle, N.P.; Reed, M.; Karam, C.J.; Maywood, E.S.; Stangherlin, A.; Chesham, J.E.; Hayter, E.A.; et al. Insulin/IGF-1 Drives PERIOD Synthesis to Entrain Circadian Rhythms with Feeding Time. Cell 2019, 177, 896-909.e20. [CrossRef] [PubMed]

138. Kelu, J.J.; Pipalia, T.G.; Hughes, S.M. Circadian regulation of muscle growth independent of locomotor activity. Proc. Natl. Acad. Sci. USA 2020, 117, 31208-31218. [CrossRef]

139. Masri, S.; Papagiannakopoulos, T.; Kinouchi, K.; Liu, Y.; Cervantes, M.; Baldi, P.; Jacks, T.; Sassone-Corsi, P. Lung Adenocarcinoma Distally Rewires Hepatic Circadian Homeostasis. Cell 2016, 165, 896-909. [CrossRef] [PubMed]

140. Haspel, J.A.; Chettimada, S.; Shaik, R.S.; Chu, J.H.; Raby, B.A.; Cernadas, M.; Carey, V.; Process, V.; Hunninghake, G.M.; Ifedigbo, E.; et al. Circadian rhythm reprogramming during lung inflammation. Nat. Commun. 2014, 5, 4753. [CrossRef]

141. Hara, R.; Wan, K.; Wakamatsu, H.; Aida, R.; Moriya, T.; Akiyama, M.; Shibata, S. Restricted feeding entrains liver clock without participation of the suprachiasmatic nucleus. Genes Cells 2001, 6, 269-278. [CrossRef]

142. Damiola, F.; Le Minh, N.; Preitner, N.; Kornmann, B.; Fleury-Olela, F.; Schibler, U. Restricted feeding uncouples circadian oscillators in peripheral tissues from the central pacemaker in the suprachiasmatic nucleus. Genes Dev. 2000, 14, $2950-2961$. [CrossRef]

143. Tognini, P.; Samad, M.; Kinouchi, K.; Liu, Y.; Helbling, J.C.; Moisan, M.P.; Eckel-Mahan, K.L.; Baldi, P.; Sassone-Corsi, P. Reshaping circadian metabolism in the suprachiasmatic nucleus and prefrontal cortex by nutritional challenge. Proc. Natl. Acad. Sci. USA 2020, 117, 29904-29913. [CrossRef]

144. Eckel-Mahan, K.L.; Patel, V.R.; de Mateo, S.; Orozco-Solis, R.; Ceglia, N.J.; Sahar, S.; Dilag-Penilla, S.A.; Dyar, K.A.; Baldi, P.; Sassone-Corsi, P. Reprogramming of the circadian clock by nutritional challenge. Cell 2013, 155, 1464-1478. [CrossRef]

145. Yasumoto, Y.; Hashimoto, C.; Nakao, R.; Yamazaki, H.; Hiroyama, H.; Nemoto, T.; Yamamoto, S.; Sakurai, M.; Oike, H.; Wada, N.; et al. Short-term feeding at the wrong time is sufficient to desynchronize peripheral clocks and induce obesity with hyperphagia, physical inactivity and metabolic disorders in mice. Metab. Clin. Exp. 2016, 65, 714-727. [CrossRef]

146. Garaulet, M.; Gómez-Abellán, P.; Alburquerque-Béjar, J.J.; Lee, Y.C.; Ordovás, J.M.; Scheer, F.A. Timing of food intake predicts weight loss effectiveness. Int. J. Obes. 2013, 37, 604-611. [CrossRef] [PubMed]

147. Garaulet, M.; Gómez-Abellán, P. Timing of food intake and obesity: A novel association. Physiol. Behav. 2014, 134, 44-50. [CrossRef] [PubMed]

148. McHill, A.W.; Phillips, A.J.; Czeisler, C.A.; Keating, L.; Yee, K.; Barger, L.K.; Garaulet, M.; Scheer, F.A.; Klerman, E.B. Later circadian timing of food intake is associated with increased body fat. Am. J. Clin. Nutr. 2017, 106, 1213-1219. [CrossRef] [PubMed] 
149. Martínez-Lozano, N.; Tvarijonaviciute, A.; Ríos, R.; Barón, I.; Scheer, F.A.J.L.; Garaulet, M. Late Eating Is Associated with Obesity, Inflammatory Markers and Circadian-Related Disturbances in School-Aged Children. Nutrients 2020, 12, 2881. [CrossRef]

150. Loh, D.H.; Jami, S.A.; Flores, R.E.; Truong, D.; Ghiani, C.A.; O’Dell, T.J.; Colwell, C.S. Misaligned feeding impairs memories. eLife 2015, 4, e09460. [CrossRef]

151. Kogevinas, M.; Espinosa, A.; Castello, A.; Gomez-Acebo, I.; Guevara, M.; Martin, V.; Amiano, P.; Alguacil, J.; Peiro, R.; Moreno, V.; et al. Effect of mistimed eating patterns on breast and prostate cancer risk (MCC-Spain Study). Int. J. Cancer 2018, 143, 2380-2389. [CrossRef]

152. Zarrinpar, A.; Chaix, A.; Yooseph, S.; Panda, S. Diet and feeding pattern affect the diurnal dynamics of the gut microbiome. Cell Metab. 2014, 20, 1006-1017. [CrossRef] [PubMed]

153. Liang, X.; Bushman, F.D.; FitzGerald, G.A. Rhythmicity of the intestinal microbiota is regulated by gender and the host circadian clock. Proc. Natl. Acad. Sci. USA 2015, 112, 10479-10484. [CrossRef]

154. Skarke, C.; Lahens, N.F.; Rhoades, S.D.; Campbell, A.; Bittinger, K.; Bailey, A.; Hoffmann, C.; Olson, R.S.; Chen, L.; Yang, G.; et al. A Pilot Characterization of the Human Chronobiome. Sci. Rep. 2017, 7, 17141. [CrossRef] [PubMed]

155. Mukherji, A.; Kobiita, A.; Ye, T.; Chambon, P. Homeostasis in intestinal epithelium is orchestrated by the circadian clock and microbiota cues transduced by TLRs. Cell 2013, 153, 812-827. [CrossRef]

156. Kuang, Z.; Wang, Y.; Li, Y.; Ye, C.; Ruhn, K.A.; Behrendt, C.L.; Olson, E.N.; Hooper, L.V. The intestinal microbiota programs diurnal rhythms in host metabolism through histone deacetylase 3. Science 2019, 365, 1428-1434. [CrossRef]

157. Makris, A.P.; Karianaki, M.; Tsamis, K.I.; Paschou, S.A. The role of the gut-brain axis in depression: Endocrine, neural, and immune pathways. Hormones 2021, 20, 1-12. [CrossRef]

158. Ying, W. NAD+/NADH and NADP+/NADPH in cellular functions and cell death: Regulation and biological consequences. Antioxid. Redox Signal. 2008, 10, 179-206. [CrossRef]

159. Nakahata, Y.; Sahar, S.; Astarita, G.; Kaluzova, M.; Sassone-Corsi, P. Circadian control of the NAD ${ }^{+}$salvage pathway by CLOCK-SIRT1. Science 2009, 324, 654-657. [CrossRef] [PubMed]

160. Ramsey, K.M.; Yoshino, J.; Brace, C.S.; Abrassart, D.; Kobayashi, Y.; Marcheva, B.; Hong, H.K.; Chong, J.L.; Buhr, E.D.; Lee, C.; et al. Circadian clock feedback cycle through NAMPT-mediated NAD ${ }^{+}$biosynthesis. Science 2009, 324, 651-654. [CrossRef]

161. Rutter, J.; Reick, M.; Wu, L.C.; McKnight, S.L. Regulation of clock and NPAS2 DNA binding by the redox state of NAD cofactors. Science 2001, 293, 510-514. [CrossRef] [PubMed]

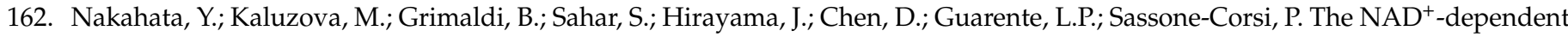
deacetylase SIRT1 modulates CLOCK-mediated chromatin remodeling and circadian control. Cell 2008, 134, 329-340. [CrossRef] [PubMed]

163. Levine, D.C.; Hong, H.; Weidemann, B.J.; Ramsey, K.M.; Affinati, A.H.; Schmidt, M.S.; Cedernaes, J.; Omura, C.; Braun, R.; Lee, C.; et al. NAD ${ }^{+}$Controls Circadian Reprogramming through PER2 Nuclear Translocation to Counter Aging. Mol. Cell 2020, 78, 835-849.e7. [CrossRef]

164. Asher, G.; Gatfield, D.; Stratmann, M.; Reinke, H.; Dibner, C.; Kreppel, F.; Mostoslavsky, R.; Alt, F.W.; Schibler, U. SIRT1 regulates circadian clock gene expression through PER2 deacetylation. Cell 2008, 134, 317-328. [CrossRef]

165. Das, A.; Huang, G.X.; Bonkowski, M.S.; Longchamp, A.; Li, C.; Schultz, M.B.; Kim, L.J.; Osborne, B.; Joshi, S.; Lu, Y.; et al. Impairment of an Endothelial NAD ${ }^{+}-\mathrm{H}_{2} \mathrm{~S}$ Signaling Network Is a Reversible Cause of Vascular Aging. Cell 2018, 173, 74-89.e20. [CrossRef]

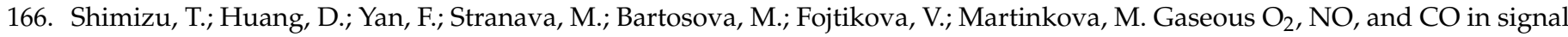
transduction: Structure and function relationships of heme-based gas sensors and heme-redox sensors. Chem. Rev. 2015, 115, 6491-6533. [CrossRef]

167. Kaasik, K.; Lee, C.C. Reciprocal regulation of haem biosynthesis and the circadian clock in mammals. Nature 2004, 430, 467-471. [CrossRef]

168. Yin, L.; Wu, N.; Curtin, J.C.; Qatanani, M.; Szwergold, N.R.; Reid, R.A.; Waitt, G.M.; Parks, D.J.; Pearce, K.H.; Wisely, G.B.; et al. Rev-erbalpha, a heme sensor that coordinates metabolic and circadian pathways. Science 2007, 318, 1786-1789. [CrossRef]

169. Raghuram, S.; Stayrook, K.R.; Huang, P.; Rogers, P.M.; Nosie, A.K.; McClure, D.B.; Burris, L.L.; Khorasanizadeh, S.; Burris, T.P.; Rastinejad, F. Identification of heme as the ligand for the orphan nuclear receptors REV-ERBalpha and REV-ERBbeta. Nat. Struct. Mol. Biol. 2007, 14, 1207-1213. [CrossRef]

170. Lukat-Rodgers, G.S.; Correia, C.; Botuyan, M.V.; Mer, G.; Rodgers, K.R. Heme-based sensing by the mammalian circadian protein CLOCK. Inorg. Chem. 2010, 49, 6349-6365. [CrossRef] [PubMed]

171. Dioum, E.M.; Rutter, J.; Tuckerman, J.R.; Gonzalez, G.; Gilles-Gonzalez, M.A.; McKnight, S.L. NPAS2: A gas-responsive transcription factor. Science 2002, 298, 2385-2387. [CrossRef]

172. Freeman, S.L.; Kwon, H.; Portolano, N.; Parkin, G.; Venkatraman Girija, U.; Basran, J.; Fielding, A.J.; Fairall, L.; Svistunenko, D.A.; Moody, P.C.E.; et al. Heme binding to human CLOCK affects interactions with the E-box. Proc. Natl. Acad. Sci. USA 2019, 116, 19911-19916. [CrossRef]

173. Guenthner, C.J.; Bickar, D.; Harrington, M.E. Heme reversibly damps PERIOD2 rhythms in mouse suprachiasmatic nucleus explants. Neuroscience 2009, 164, 832-841. [CrossRef]

174. Klemz, R.; Reischl, S.; Wallach, T.; Witte, N.; Jurchott, K.; Klemz, S.; Lang, V.; Lorenzen, S.; Knauer, M.; Heidenreich, S.; et al. Reciprocal regulation of carbon monoxide metabolism and the circadian clock. Nat. Struct. Mol. Biol. 2017, 24, 15-22. [CrossRef] 
175. Minegishi, S.; Sagami, I.; Negi, S.; Kano, K.; Kitagishi, H. Circadian clock disruption by selective removal of endogenous carbon monoxide. Sci. Rep. 2018, 8, 11996. [CrossRef] [PubMed]

176. Wang, M.; Yang, X.; Pan, Z.; Wang, Y.; De La Cruz, L.K.; Wang, B.; Tan, C. Towards "CO in a pill”: Pharmacokinetic studies of carbon monoxide prodrugs in mice. J. Control. Release 2020, 327, 174-185. [CrossRef] [PubMed]

177. Siracusa, R.; Schaufler, A.; Calabrese, V.; Fuller, P.M.; Otterbein, L.E. Carbon Monoxide: From Poison to Clinical Trials. Trends Pharmacol. Sci. 2021. [CrossRef] [PubMed]

178. Correa-Costa, M.; Gallo, D.; Csizmadia, E.; Gomperts, E.; Lieberum, J.L.; Hauser, C.J.; Ji, X.; Wang, B.; Camara, N.O.S.; Robson, S.C.; et al. Carbon monoxide protects the kidney through the central circadian clock and CD39. Proc. Natl. Acad. Sci. USA 2018, 115, E2302-E2310. [CrossRef]

179. Schallner, N.; Lieberum, J.L.; Gallo, D.; LeBlanc, R.H., 3rd; Fuller, P.M.; Hanafy, K.A.; Otterbein, L.E. Carbon Monoxide Preserves Circadian Rhythm to Reduce the Severity of Subarachnoid Hemorrhage in Mice. Stroke 2017, 48, 2565-2573. [CrossRef]

180. Emami, Z.; Mesbah Namin, A.; Kojuri, J.; Mashayekhi Jalali, F.; Rasti, M. Expression and Activity of Platelet Endothelial Nitric Oxide Synthase Are Decreased in Patients with Coronary Thrombosis and Stenosis. Avicenna J. Med. Biotechnol. 2019, 11, 88-93.

181. Ayers, N.A.; Kapas, L.; Krueger, J.M. Circadian variation of nitric oxide synthase activity and cytosolic protein levels in rat brain. Brain Res. 1996, 707, 127-130. [CrossRef]

182. Mitome, M.; Shirakawa, T.; Oshima, S.; Nakamura, W.; Oguchi, H. Circadian rhythm of nitric oxide production in the dorsal region of the suprachiasmatic nucleus in rats. Neurosci. Lett. 2001, 303, 161-164. [CrossRef]

183. Tunctan, B.; Weigl, Y.; Dotan, A.; Peleg, L.; Zengil, H.; Ashkenazi, I.; Abacioglu, N. Circadian variation of nitric oxide synthase activity in mouse tissue. Chronobiol. Int. 2002, 19, 393-404. [CrossRef] [PubMed]

184. Uludag, O.; Tunctan, B.; Guney, H.Z.; Uluoglu, C.; Altug, S.; Zengil, H.; Abacioglu, N. Temporal variation in serum nitrite levels in rats and mice. Chronobiol. Int. 1999, 16, 527-532. [CrossRef] [PubMed]

185. Machado-Nils, A.V.; de Faria, L.O.; Vieira, A.S.; Teixeira, S.A.; Muscara, M.N.; Ferrari, E.A. Daily cycling of nitric oxide synthase (NOS) in the hippocampus of pigeons (C. livia). J. Circadian Rhythms 2013, 11, 12. [CrossRef]

186. Denniff, M.; Turrell, H.E.; Vanezis, A.; Rodrigo, G.C. The time-of-day variation in vascular smooth muscle contractility depends on a nitric oxide signalling pathway. J. Mol. Cell. Cardiol. 2014, 66, 133-140. [CrossRef] [PubMed]

187. Mastronardi, C.A.; Yu, W.H.; McCann, S.M. Resting and circadian release of nitric oxide is controlled by leptin in male rats. Proc. Natl. Acad. Sci. USA 2002, 99, 5721-5726. [CrossRef]

188. Viswambharan, H.; Carvas, J.M.; Antic, V.; Marecic, A.; Jud, C.; Zaugg, C.E.; Ming, X.F.; Montani, J.P.; Albrecht, U.; Yang, Z. Mutation of the circadian clock gene Per2 alters vascular endothelial function. Circulation 2007, 115, 2188-2195. [CrossRef] [PubMed]

189. Anea, C.B.; Cheng, B.; Sharma, S.; Kumar, S.; Caldwell, R.W.; Yao, L.; Ali, M.I.; Merloiu, A.M.; Stepp, D.W.; Black, S.M.; et al. Increased superoxide and endothelial NO synthase uncoupling in blood vessels of Bmal1-knockout mice. Circ. Res. 2012, 111, 1157-1165. [CrossRef] [PubMed]

190. Kanabrocki, E.L.; George, M.; Hermida, R.C.; Messmore, H.L.; Ryan, M.D.; Ayala, D.E.; Hoppensteadt, D.A.; Fareed, J.; Bremner, F.W.; Third, J.L.; et al. Day-night variations in blood levels of nitric oxide, T-TFPI, and E-selectin. Clin. Appl. Thromb. Hemost. 2001, 7, 339-345. [CrossRef]

191. Kriegsfeld, L.J.; Drazen, D.L.; Nelson, R.J. Circadian organization in male mice lacking the gene for endothelial nitric oxide synthase (eNOS-/-). J. Biol. Rhythms 2001, 16, 142-148. [CrossRef]

192. Arraj, M.; Lemmer, B. Endothelial nitric oxide is not involved in circadian rhythm generation of blood pressure: Experiments in wild-type C57 and eNOS knock-out mice under light-dark and free-run conditions. Chronobiol. Int. 2007, 24, 1231-1240. [CrossRef]

193. Kunieda, T.; Minamino, T.; Miura, K.; Katsuno, T.; Tateno, K.; Miyauchi, H.; Kaneko, S.; Bradfield, C.A.; FitzGerald, G.A.; Komuro, I. Reduced nitric oxide causes age-associated impairment of circadian rhythmicity. Circ. Res. 2008, 102, 607-614. [CrossRef] [PubMed]

194. Melo, L.; Golombek, D.A.; Ralph, M.R. Regulation of circadian photic responses by nitric oxide. J. Biol. Rhythms 1997, 12, 319-326. [CrossRef] [PubMed]

195. Kozlov, A.; Koch, R.; Nagoshi, E. Nitric oxide mediates neuro-glial interaction that shapes Drosophila circadian behavior. PLoS Genet. 2020, 16, e1008312. [CrossRef]

196. Peek, C.B. Metabolic Implications of Circadian-HIF Crosstalk. Trends Endocrinol. Metab. 2020, 31, 459-468. [CrossRef]

197. Luers, H.; Hillmann, K.; Litniewski, J.; Bereiter-Hahn, J. Acoustic microscopy of cultured cells. Distribution of forces and cytoskeletal elements. Cell Biophys 1991, 18, 279-293. [CrossRef] [PubMed]

198. Bosco, G.; Ionadi, A.; Panico, S.; Faralli, F.; Gagliardi, R.; Data, P.; Mortola, J.P. Effects of hypoxia on the circadian patterns in men. High Alt. Med. Biol. 2003, 4, 305-318. [CrossRef]

199. Coste, O.; Beaumont, M.; Batejat, D.; Beers, P.V.; Touitou, Y. Prolonged mild hypoxia modifies human circadian core body temperature and may be associated with sleep disturbances. Chronobiol. Int. 2004, 21, 419-433. [CrossRef]

200. Coste, O.; Van Beers, P.; Touitou, Y. Hypoxia-induced changes in recovery sleep, core body temperature, urinary 6sulphatoxymelatonin and free cortisol after a simulated long-duration flight. J. Sleep Res. 2009, 18, 454-465. [CrossRef] 
201. Adamovich, Y.; Ladeuix, B.; Sobel, J.; Manella, G.; Neufeld-Cohen, A.; Assadi, M.H.; Golik, M.; Kuperman, Y.; Tarasiuk, A.; Koeners, M.P.; et al. Oxygen and Carbon Dioxide Rhythms Are Circadian Clock Controlled and Differentially Directed by Behavioral Signals. Cell Metab. 2019, 29, 1092-1103.e3. [CrossRef] [PubMed]

202. Adamovich, Y.; Ladeuix, B.; Golik, M.; Koeners, M.P.; Asher, G. Rhythmic Oxygen Levels Reset Circadian Clocks through HIF1alpha. Cell Metab. 2017, 25, 93-101. [CrossRef] [PubMed]

203. Banerjee, J.; Canamar, C.P.; Voyageur, C.; Tangpraphaphorn, S.; Lemus, A.; Coffey, C., Jr.; Wald-Dickler, N.; Holtom, P.; Shoenberger, J.; Bowdish, M.; et al. Mortality and Readmission Rates Among Patients With COVID-19 After Discharge From Acute Care Setting With Supplemental Oxygen. JAMA Netw. Open 2021, 4, e213990. [CrossRef]

204. Sengupta, S.; Ince, L.; Sartor, F.; Borrmann, H.; Zhuang, X.; Naik, A.; Curtis, A.; McKeating, J.A. Clocks, Viruses, and Immunity: Lessons for the COVID-19 Pandemic. J. Biol. Rhythms 2021, 36, 23-34. [CrossRef]

205. Balaban, R.S.; Nemoto, S.; Finkel, T. Mitochondria, oxidants, and aging. Cell 2005, 120, 483-495. [CrossRef] [PubMed]

206. Qian, H.; Hu, B.; Yu, S.; Pan, X.; Wu, T.; Fu, Z. The effects of hydrogen peroxide on the circadian rhythms of Microcystis aeruginosa. PLoS ONE 2012, 7, e33347. [CrossRef]

207. Grover, D.; Ford, D.; Brown, C.; Hoe, N.; Erdem, A.; Tavare, S.; Tower, J. Hydrogen peroxide stimulates activity and alters behavior in Drosophila melanogaster. PLoS ONE 2009, 4, e7580. [CrossRef]

208. Pei, J.F.; Li, X.K.; Li, W.Q.; Gao, Q.; Zhang, Y.; Wang, X.M.; Fu, J.Q.; Cui, S.S.; Qu, J.H.; Zhao, X.; et al. Diurnal oscillations of endogenous $\mathrm{H} 2 \mathrm{O} 2$ sustained by p66(Shc) regulate circadian clocks. Nat. Cell Biol. 2019, 21, 1553-1564. [CrossRef]

209. Harkness, J.H.; Bushana, P.N.; Todd, R.P.; Clegern, W.C.; Sorg, B.A.; Wisor, J.P. Sleep disruption elevates oxidative stress in parvalbumin-positive cells of the rat cerebral cortex. Sleep 2019, 42, zsy201. [CrossRef]

210. Vaccaro, A.; Kaplan Dor, Y.; Nambara, K.; Pollina, E.A.; Lin, C.; Greenberg, M.E.; Rogulja, D. Sleep Loss Can Cause Death through Accumulation of Reactive Oxygen Species in the Gut. Cell 2020, 181, 1307-1328.e15. [CrossRef]

211. Fanjul-Moles, M.L.; López-Riquelme, G.O. Relationship between Oxidative Stress, Circadian Rhythms, and AMD. Oxidative Med. Cell Longev. 2016, 2016, 7420637. [CrossRef]

212. Hine, C.; Mitchell, J.R. Calorie restriction and methionine restriction in control of endogenous hydrogen sulfide production by the transsulfuration pathway. Exp. Gerontol. 2015, 68, 26-32. [CrossRef]

213. Kimura, H. The physiological role of hydrogen sulfide and beyond. Nitric Oxide 2014, 41, 4-10. [CrossRef]

214. Zhang, Y.; Tang, Z.H.; Ren, Z.; Qu, S.L.; Liu, M.H.; Liu, L.S.; Jiang, Z.S. Hydrogen sulfide, the next potent preventive and therapeutic agent in aging and age-associated diseases. Mol. Cell. Biol. 2013, 33, 1104-1113. [CrossRef]

215. Shang, Z.; Lu, C.; Chen, S.; Hua, L.; Qian, R. Effect of $\mathrm{H}_{2} \mathrm{~S}$ on the circadian rhythm of mouse hepatocytes. Lipids Health Dis 2012, 11, 23. [CrossRef]

216. Jin, S.; Tan, B.; Teng, X.; Meng, R.; Jiao, X.; Tian, D.; Xiao, L.; Xue, H.; Guo, Q.; Duan, X.; et al. Diurnal Fluctuations in Plasma Hydrogen Sulfide of the Mice. Front. Pharmacol. 2017, 8, 682. [CrossRef] [PubMed]

217. Scuffi, D.; Nietzel, T.; Di Fino, L.M.; Meyer, A.J.; Lamattina, L.; Schwarzlander, M.; Laxalt, A.M.; Garcia-Mata, C. Hydrogen Sulfide Increases Production of NADPH Oxidase-Dependent Hydrogen Peroxide and Phospholipase D-Derived Phosphatidic Acid in Guard Cell Signaling. Plant Physiol. 2018, 176, 2532-2542. [CrossRef] [PubMed]

218. Shaposhnikov, M.; Proshkina, E.; Koval, L.; Zemskaya, N.; Zhavoronkov, A.; Moskalev, A. Overexpression of CBS and CSE genes affects lifespan, stress resistance and locomotor activity in Drosophila melanogaster. Aging 2018, 10, 3260-3272. [CrossRef]

219. Zhang, H.; Dai, J.; Tian, D.; Xiao, L.; Xue, H.; Guo, Q.; Zhang, X.; Teng, X.; Jin, S.; Wu, Y. Hydrogen Sulfide Restored the Diurnal Variation in Cardiac Function of Aging Mice. Oxidative Med. Cell. Longev. 2021, 2021, 8841575. [CrossRef]

220. Penarrubia, L.; Andres-Colas, N.; Moreno, J.; Puig, S. Regulation of copper transport in Arabidopsis thaliana: A biochemical oscillator? J. Biol. Inorg. Chem. 2010, 15, 29-36. [CrossRef] [PubMed]

221. Guo, F.; Chen, X.; Rosbash, M. Temporal calcium profiling of specific circadian neurons in freely moving flies. Proc. Natl. Acad. Sci. USA 2017, 114, E8780-E8787. [CrossRef] [PubMed]

222. Love, J.; Dodd, A.N.; Webb, A.A. Circadian and diurnal calcium oscillations encode photoperiodic information in Arabidopsis. Plant Cell 2004, 16, 956-966. [CrossRef]

223. Zhang, S.; Wu, Q.R.; Liu, L.L.; Zhang, H.M.; Gao, J.W.; Pei, Z.M. Osmotic stress alters circadian cytosolic Ca ${ }^{2+}$ oscillations and OSCA1 is required in circadian gated stress adaptation. Plant Signal. Behav. 2020, 15, 1836883. [CrossRef]

224. Lundkvist, G.B.; Kwak, Y.; Davis, E.K.; Tei, H.; Block, G.D. A calcium flux is required for circadian rhythm generation in mammalian pacemaker neurons. J. Neurosci. Off. J. Soc. Neurosci. 2005, 25, 7682-7686. [CrossRef]

225. Perea-Garcia, A.; Andres-Borderia, A.; Mayo de Andres, S.; Sanz, A.; Davis, A.M.; Davis, S.J.; Huijser, P.; Penarrubia, L. Modulation of copper deficiency responses by diurnal and circadian rhythms in Arabidopsis thaliana. J. Exp. Bot. 2016, 67, 391-403. [CrossRef] [PubMed]

226. Perea-Garcia, A.; Sanz, A.; Moreno, J.; Andres-Borderia, A.; de Andres, S.M.; Davis, A.M.; Huijser, P.; Davis, S.J.; Penarrubia, L. Daily rhythmicity of high affinity copper transport. Plant Signal. Behav. 2016, 11, e1140291. [CrossRef]

227. Perea-Garcia, A.; Andres-Colas, N.; Penarrubia, L. Copper homeostasis influences the circadian clock in Arabidopsis. Plant Signal. Behav. 2010, 5, 1237-1240. [CrossRef]

228. Lifschitz, M.D.; Henkin, R.I. Circadian variation in copper and zinc in man. J. Appl. Physiol. 1971, 31, 88-92. [CrossRef]

229. Aono, H.; Araki, S. Circadian rhythms in the urinary excretion of heavy metals and organic substances in metal workers in relation to renal excretory mechanism: Profile analysis. Int. Arch. Occup. Environ. Health 1988, 60, 1-6. [CrossRef] [PubMed] 
230. Araki, S.; Murata, K.; Yokoyama, K.; Yanagihara, S.; Niinuma, Y.; Yamamoto, R.; Ishihara, N. Circadian rhythms in the urinary excretion of metals and organic substances in "healthy" men. Arch. Environ. Health 1983, 38, 360-366. [CrossRef]

231. Kanabrocki, E.L.; Sothern, R.B.; Ryan, M.D.; Kahn, S.; Augustine, G.; Johnson, C.; Foley, S.; Gathing, A.; Eastman, G.; Friedman, N.; et al. Circadian characteristics of serum calcium, magnesium and eight trace elements and of their metallo-moieties in urine of healthy middle-aged men. Clin. Ter. 2008, 159, 329-346. [PubMed]

232. Flourakis, M.; Kula-Eversole, E.; Hutchison, A.L.; Han, T.H.; Aranda, K.; Moose, D.L.; White, K.P.; Dinner, A.R.; Lear, B.C.; Ren, D.; et al. A Conserved Bicycle Model for Circadian Clock Control of Membrane Excitability. Cell 2015, 162, 836-848. [CrossRef]

233. Xie, L.; Gao, S.; Alcaire, S.M.; Aoyagi, K.; Wang, Y.; Griffin, J.K.; Stagljar, I.; Nagamatsu, S.; Zhen, M. NLF-1 delivers a sodium leak channel to regulate neuronal excitability and modulate rhythmic locomotion. Neuron 2013, 77, 1069-1082. [CrossRef]

234. Ding, F.; O’Donnell, J.; Xu, Q.; Kang, N.; Goldman, N.; Nedergaard, M. Changes in the composition of brain interstitial ions control the sleep-wake cycle. Science 2016, 352, 550-555. [CrossRef] [PubMed]

235. Shim, H.S.; Kim, H.; Lee, J.; Son, G.H.; Cho, S.; Oh, T.H.; Kang, S.H.; Seen, D.S.; Lee, K.H.; Kim, K. Rapid activation of CLOCK by $\mathrm{Ca}^{2+}$-dependent protein kinase $\mathrm{C}$ mediates resetting of the mammalian circadian clock. EMBO Rep. 2007, 8, 366-371. [CrossRef]

236. Brancaccio, M.; Maywood, E.S.; Chesham, J.E.; Loudon, A.S.; Hastings, M.H. A Gq-Ca2+ axis controls circuit-level encoding of circadian time in the suprachiasmatic nucleus. Neuron 2013, 78, 714-728. [CrossRef]

237. Harrisingh, M.C.; Wu, Y.; Lnenicka, G.A.; Nitabach, M.N. Intracellular $\mathrm{Ca}^{2+}$ regulates free-running circadian clock oscillation in vivo. J. Neurosci. Off. J. Soc. Neurosci. 2007, 27, 12489-12499. [CrossRef] [PubMed]

238. Palacios-Munoz, A.; Ewer, J. Calcium and cAMP directly modulate the speed of the Drosophila circadian clock. PLoS Genet. 2018, 14, e1007433. [CrossRef]

239. Yamada, Y.; Prosser, R.A. Copper in the suprachiasmatic circadian clock: A possible link between multiple circadian oscillators. Eur. J. Neurosci. 2020, 51, 47-70. [CrossRef]

240. Feeney, K.A.; Hansen, L.L.; Putker, M.; Olivares-Yanez, C.; Day, J.; Eades, L.J.; Larrondo, L.F.; Hoyle, N.P.; O’Neill, J.S.; van Ooijen, G. Daily magnesium fluxes regulate cellular timekeeping and energy balance. Nature 2016, 532, 375-379. [CrossRef]

241. Zhang, S.L.; Yue, Z.; Arnold, D.M.; Artiushin, G.; Sehgal, A. A Circadian Clock in the Blood-Brain Barrier Regulates Xenobiotic Efflux. Cell 2018, 173, 130-139.e10. [CrossRef] [PubMed]

242. Zhang, S.L.; Lahens, N.F.; Yue, Z.; Arnold, D.M.; Pakstis, P.P.; Schwarz, J.E.; Sehgal, A. A circadian clock regulates efflux by the blood-brain barrier in mice and human cells. Nat. Commun. 2021, 12, 617. [CrossRef]

243. Cuddapah, V.A.; Zhang, S.L.; Sehgal, A. Regulation of the Blood-Brain Barrier by Circadian Rhythms and Sleep. Trends Neurosci. 2019, 42, 500-510. [CrossRef] [PubMed]

244. Henslee, E.A.; Crosby, P.; Kitcatt, S.J.; Parry, J.S.W.; Bernardini, A.; Abdallat, R.G.; Braun, G.; Fatoyinbo, H.O.; Harrison, E.J.; Edgar, R.S.; et al. Rhythmic potassium transport regulates the circadian clock in human red blood cells. Nat. Commun. 2017, 8, 1978. [CrossRef]

245. Hu, Y.; Spengler, M.L.; Kuropatwinski, K.K.; Comas-Soberats, M.; Jackson, M.; Chernov, M.V.; Gleiberman, A.S.; Fedtsova, N.; Rustum, Y.M.; Gudkov, A.V.; et al. Selenium is a modulator of circadian clock that protects mice from the toxicity of a chemotherapeutic drug via upregulation of the core clock protein, BMAL1. Oncotarget 2011, 2, 1279-1290. [CrossRef] [PubMed]

246. Simcox, J.A.; Mitchell, T.C.; Gao, Y.; Just, S.F.; Cooksey, R.; Cox, J.; Ajioka, R.; Jones, D.; Lee, S.H.; King, D.; et al. Dietary iron controls circadian hepatic glucose metabolism through heme synthesis. Diabetes 2015, 64, 1108-1119. [CrossRef]

247. Gizowski, C.; Bourque, C.W. Sodium regulates clock time and output via an excitatory GABAergic pathway. Nature 2020, 583, 421-424. [CrossRef] [PubMed] 